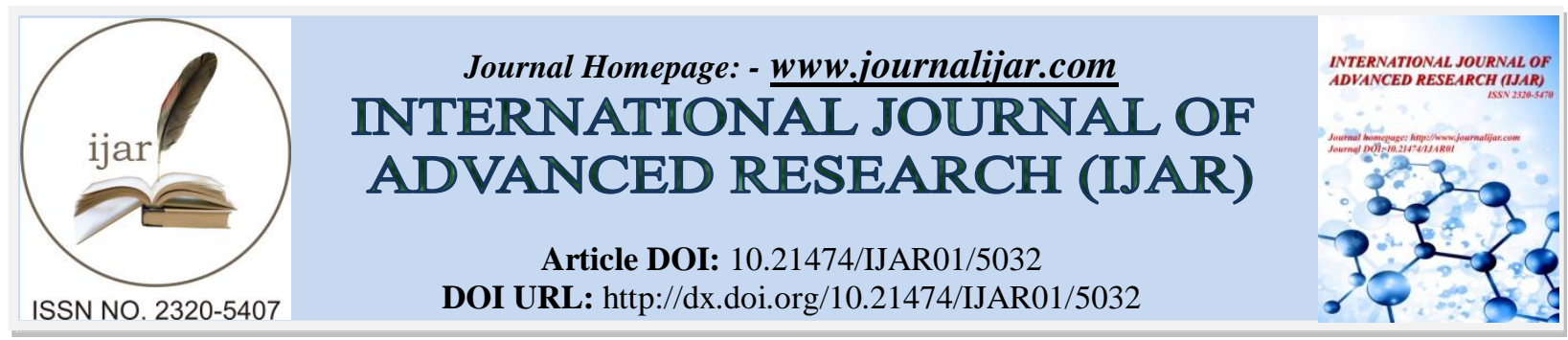

RESEARCH ARTICLE

\title{
CYSTS OF THE OROFACIAL REGION: A 35 YEAR DEMOGRAPHIC DATA AT AN INDIAN DENTAL INSTITUTE.
}

\section{Tabita Joy C. MDS ${ }^{1}$, "Sweety Bafna, MDS', J. V. Tupkari. MDS ${ }^{3}$ and Manisha Ahire, MDS ${ }^{4}$.}

1. Associate Professor, Department of Oral Pathology and Microbiology, Government Dental College and Hospital, Mumbai.

2. Department of Oral Pathology and Microbiology, Government Dental College and Hospital, Mumbai

3. Prof. \& Head, Department of Oral Pathology and Microbiology, Government Dental College and Hospital, Mumbai.

4. Lecturer, Department of Oral Pathology and Microbiology, Government Dental College and Hospital, Mumbai.

\section{Manuscript Info}

(..........................

Manuscript History

Received: 01 June 2017

Final Accepted: 03 July 2017

Published: August 2017

Key words:-

Orofacial cyst, Odontogenic cyst, nonodontogenic cyst, demographic data of oral cyst

\section{Abstract}

Introduction: The odontogenic cysts form a significant portion of the pathologies affecting the orofacial structures and pose a challenge for clinical diagnosis. The geographic distribution may be varied and thus determining the distribution of cysts of the oral and maxillofacial regions, according to age, gender and anatomical distribution may aid in the diagnosis.

Methods: Dental records of histologically diagnosed biopsy specimens of cysts of oro-facial region were procured from the period of January 1981 to December 2015.The clinical data and radiological findings and final histopathological diagnosis were recorded and subjected to statistical analysis .

Results: comparing prevalence of all the cystic lesions radicular cysts were most prevalent with $47.58 \%$, followed by odontogenic keratocyst $11.75 \%$, mucocele $11.67 \%$, dentigerous cyst $10.14 \%$ and unclassifiable odontogenic cysts $9.09 \%$ were encountered apart from few cases of other cystic lesions .

Conclusions:. The present study provides a demographic data on a large series of cystic lesions in india showing a varied geographical presentation. As the management of pathologic lesions are often dictated by the diagnosis, the clinicopathologic features are necessary for accurate diagnosis and also for differentiating aggressive cystic lesions.

Copy Right, IJAR, 2017,. All rights reserved.

\section{Introduction:-}

Cysts of the oral and maxillofacial region, are one of the most common lesions among the oral biopsies encountered in the practice of Oral Pathology, and have continued to evoke considerable interest among clinicians and pathologists through past ages. Lesions of the jaws interpreted as cysts have been found in mummified specimens from the predynastic era $(c .4500 \mathrm{BC})$ and from the $5^{\text {th }}$ dynasty $(c .2800 \mathrm{BC})$ in Egypt till date. ${ }^{52}$ 
A number of studies have been conducted in the recent past related to the prevalence of cystic lesions in several countries and with different ethnic groups. However, literature review reveals that very few articles have been published with regards to the epidemiology of cystic lesions with a systematic approach in India. And these seem to be of limited use in international comparative studies as neither large number of cases have been reported, nor recorded over a period of many years systematically. It's said that larger the sample size, more accurate would be the age, gender and other demographic data, hence, the present study was undertaken to overcome these factors. The objective was to determine the distribution of cysts of the oral and maxillofacial regions, diagnosed histologically over a period of 35 years in an Indian Dental Institute according to age, gender and anatomical distribution. Further it was also aimed to compare this data with those reported previously in different parts of the world.

\section{Materials and Methods:-}

After approval by the ethics committee the dental records of histologically diagnosed biopsy specimens of cysts of oro-facial region were procured and evaluated from the archival biopsy report files of the Department of Oral Pathology and Microbiology, Government Dental College and Hospital, Mumbai, India from the period of January 1981 to December 2015.

The information sought on each case included age, sex, site of lesion, duration, history of trauma, clinical presentation, provisional diagnosis, radiographic picture and histological diagnosis.

Patients age was reported as decade of life, from the first to the last decade as found in the records. In order, to determine the site of lesions, the anterior region was defined as the canine-to canine segment. The posterior region was defined as the premolar and molar region, including the ramus of the mandible. The anterior-posterior segment was defined as involving both the anterior and posterior segments. Records that had some lacunae were not included for statistical analysis.

The Oro-facial cysts were basically classified according to the classification given by Shear and Paul Speight $(2007)^{52}$ into three main groups i.e. Cysts of the jaws, Cysts associated with the maxillary antrum and Cysts of the soft tissues of the mouth, face, neck and salivary glands.(Table 1)

Statistical analysis was carried out on the data acquired .The Microsoft Excel TM software was used for data analysis and construction of the graphs.

\section{Results:-}

Out of the total 6509 oral biopsies received during the period from January 1981 to December 2015, there were 1242 cases of cysts of the orofacial region, i.e.19.08\% of total biopsies. (Figure1: 35 Year Distribution of 1242 cases of cysts of oro-facial region $\{1981-2015\}$ )

The cysts of the jaws accounted for about $86.71 \%$ of all cystic lesions, the cysts of the maxillary antrum was $0.32 \%$, while cysts of the soft tissues of the mouth, face, neck and salivary glands was $12.96 \%$. ( Table 1)

Comparing prevalence of all the cystic lesions radicular cysts were most prevalent with $47.58 \%$, followed by odontogenic keratocyst $11.75 \%$,mucocele $11.67 \%$,dentigerous cyst $10.14 \%$, unclassifiable odontogenic cysts $9.09 \%$,residual cyst $5.95 \%$, nasolabial cyst $0.56 \%$, while calcifying odontogenic cyst and dermoid cyst was $0.48 \%$, nasopalatine and epidermoid cysts $0.4 \%$ each, followed by, sebaceous cysts, orthokeratinized odontogenic cyst, and postoperative maxillary cyst $0.24 \%$,glandular odontogenic cyst and lateral periodontal cyst $0.16 \%$, and only one case $(0.08 \%)$ each of para-dental cyst ,traumatic bone cyst, mucocele of maxillary antrum, lymphoepithelial (branchial) cyst and parasitic cyst ( cysticercuscellulosae) were encountered. (Table 2)

Among the cysts of the jaw the epithelial lined cysts accounted to almost $99.91 \%$, while non-epithelial cyst was only $0.09 \%$. The epithelial lined cysts on further classification into developmental and inflammatory were $38.10 \%$ and $61.89 \%$ respectively. Among the developmental cysts, the odontogenic were $97.07 \%$ and non-odontogenic cysts $2.93 \%$.

The odontogenic cysts accounted for $85.67 \%$ (1064 cases) of the orofacial cysts and $16.35 \%$ of all the pathological specimens reported in the department. 
The maximum cases of orofacial cysts were found to be in the age range of 21-30 years of age group (Table 3) and male predominance was found with male: female ratio of 1.81:1.(Table 2)

The most common diagnosed inflammatory odontogenic cysts were Radicular cyst, Residual cyst and Paradental cyst .The radicular cyst was found to be the most common representing $47.58 \%$ of all the cysts of the orofacial region with M: F ratio of 1.53:1. Of the 591 cases, where the site of occurrence was indicated, the maxilla was the most commonly affected site with $63.48 \%$ cases and $35.13 \%$ cases in the mandible while the site was not mentioned in $1.39 \%$ cases. The predominant location was maxillary anterior region with $43.83 \%$ cases. The prevalence of radicular cyst was highest in the age group of 21-30 years. Histopathologically $269(46.78 \%)$ cases which did not reveal the cystic lining were stated as infected dental cysts. But correlating with their clinical and radiographic findings we have grouped them with the radicular cysts.

Residual cysts accounted for $5.95 \%$ cases of oro-facial cyst. The male to female ratio was $1.39: 1$ and the predominant age group noted was 21-30 years. Both the jaws were equally affected with the most common site being mandibular posterior ( $43.24 \%$ cases).

While a single case $(0.08 \%)$ of paradental cyst was noted in a 31 year old male patient with a history of 5 years duration. Site involved was maxillary anterior region and the lesion measured approximately $3 \mathrm{~cm}$ in size.

Among the developmental odontogenic cysts the different cysts encountered were odontogenic keratocyst, orthokeratinized odontogenic cyst,dentigerous cyst, calcifying odontogenic cyst, lateral periodontal cyst and glandular odontogenic cyst. The cases reported as Odontogenic keratocyst / Keratocystic odontogenic tumor/ /Primordial Cyst were included under one group as odontogenic keratocyst. They were $11.75 \%$ of all the orofacial cysts with maximum incidence in the age group of 11-20 years of age and male: female ratio of 1.84: 1 . The site of occurrence was $31.65 \%$ in maxilla, $64.75 \%$ in mandible, $1.44 \%$ cases involving both maxilla and mandible; however, for $2.16 \%$ cases the site was not mentioned. The specific predominant location was mandibular posterior region with $63.31 \%$ cases. The syndromic cases of OKC accounted to $5.48 \%$ (8 cases), OKC with secondary infection was $30.14 \%$ (44 cases), OKC with microcyst formation $2.05 \%$ (3 cases), $1.37 \%$ (2cases) were recurrent and $90.96 \%$ ( 89 cases) were characteristic sporadic OKC.

Only 3 cases $(0.24 \%)$ of orthokeratinized odontogenic cyst were reported. One patient was male and other two females $\&$ were in their $2^{\text {rd }}$ to $5^{\text {th }}$ decade. In all 3 cases posterior mandible was the involved site, two cases showing unilocular radiolucency mimicking dentigerous cyst radiographically. The lesion was associated with impacted tooth in two cases while one had history of extraction of impacted third molar.

The dentigerous cyst was third common oro-facial cyst with $10.14 \%$ cases. The gender distribution showed male predominance with male: female ratio of 2.7:1. The maximum number of cases were noted in 11-20 years of age group. The site of presentation was $47.62 \%$ in maxilla, $50.79 \%$ in mandible and was not mentioned for $1.59 \%$ cases. Clinically the posterior mandible was the most commonly affected site (46.82\% cases). Histologically almost $50 \%$ of the dentigerous cysts were associated with secondary infection.

The calcifying odontogenic cyst accounted for $0.48 \%$ cases with equal gender distribution and age range from 14 to 25 years. Of the 6 cases reported 5 were in maxilla and one in mandible.

Lateral periodontal cyst was reported in 2 cases $(0.16 \%)$ one male and one female, aged 28 and 55 years involving mandibular posterior region with impacted tooth and pericoronal radiolucency in one case and watery fluid on aspiration biopsy.

Glandular odontogenic cyst was reported in 2 cases $(0.16 \%)$, one male and one female aged 44 and 20 years respectively. In both the cases site involved was mandibular posterior region.

The cases which were clinically and radiographically diagnosed as developmental cysts but, histologically where the specific odontogenic cyst type could not be identified, due to absence of epithelial lining and inflammation as well as lacunae in clinical information, these cases were classified as an unclassified odontogenic cyst group. They accounted to $9.09 \%$ cases with male to female ratio of 1.9:1. The maximum cases were noted in the age group of 2130 years. The mandible was commonly involved than maxilla with the ratio of 1.73:1. The provisional diagnosis 
mentioned for these cases included dentigerous cyst, odontogenic keratocyst, ameloblastoma, globulomaxillary cyst, lateral periodontal cyst and nasopalatine cyst.

The non-odontogenic epithelial cysts included nasolabial cyst and nasopalatine cyst. Nasolabial cyst comprised of $0.56 \%$ cases with male to female ratio of $1.33: 1$. The age ranged from 23 to 58 years.

Only $5(0.4 \%)$ cases of nasopalatine cyst were encountered. Among the five cases four were males and one was female and age ranged from 19 to 55 years. Maxillary anterior region was commonly involved whereas only one case was seen extending to the maxillary posterior region.

The non-epithelial cysts of the jaws included only one case $(0.08 \%)$ of traumatic bone cyst in a 13 year old patient involving the right mandibular posterior region measuring $3.5 \mathrm{cms}$ in size.

The cysts of the maxillary antrum included 3 cases $(0.24 \%)$ of post-operative maxillary (Surgical ciliated cyst) cyst and one case of mucocele. The post-operative cyst of the maxillary antrum was observed in 2 males and 1 female, occurring in the third to fourth decade of life. The patient gave history of previous surgery 9 and 25 years back. Mucocele of the maxillary antrum was noted in a $(0.08 \%) 38$ year old male patient, with history of pus discharge from the nose.

The cysts of the soft tissues of the mouth, face, neck and salivary glands included predominantly mucoceles of the minor salivary glands which accounted to $11.67 \%$ of all cysts and formed the third largest group of lesions with male: female ratio of 2.6:1. Majority of the cases were of mucous extravasation phenomenon. The most common site was labial mucosa $(78.47 \%)$, the other involved sites included buccal mucosa $(8.33 \%)$, floor of the mouth (7.64\%), ventral surface of tongue (1.39\%) and preauricular region, submandibular region and sublingual region $(0.69 \%)$ while the site was not known in 3 cases(2.08\%). Majority of the cases was found in the age group of 21-30 years.

All the six cases $(0.48 \%)$ of dermoid cysts were found in the males with a varied age range from 8 to 76 years. The site involved was infra and supra orbital region, posterior mandibular region of the face and lower lip.

Epidermoid cysts were five (0.4\%) in number with age ranging from 25 to 76 years, predominant in males with ratio of 4:1 and buccal mucosa was the commonly involved site.

All the sebaceous cyst cases $(0.24 \%)$ were noted in the males, belonging to second or fourth decade. The site involved were preauricular region, ala of the nose and parasymphyseal body region. One case was associated with pus discharge, another with a draining sinus and punctum was noted over the skin in one case.

A single case $(0.08 \%)$ of benign lymphoepithelial cyst was recorded in a 55 year old male patient with 2 years duration measuring $1 \mathrm{~cm}$ in size and occurring on the buccal mucosa.

Also a single parasitic cyst i.e. cysticercus cellulosae was reported on the upper lip in a 14 year old male patient with duration of 1 year. Lymphadenopathy was recorded in both right and left submandibular glands.

The complications associated with the odontogenic cysts were recorded separately and not included under the cystic lesions. Of these 14 cases of unclassified cystic lesions, 6 cases of dentigerous cyst and 5 cases of odontogenic keratocyst showed ameloblastomatous transformation accounting to a total of 25 cases. Squamous odontogenic tumor like proliferation in a residual cyst and one case of $\mathrm{OKC}$ with ameloblastic fibroodontome was noted. An odontogenic keratocyst showed malignant transformation, while another case of odontogenic cyst showed transformation into mucoepidermoid carcinoma. (Table 4)

\section{Discussion:-}

A myriad of cysts occur in the oral and maxillofacial region and may arise histogenetically from the developing orofacial apparatus and their remnants. These lesions are characterized by an expansile non-infiltrating growth, resulting in a smooth and usually unilocular cavity containing fluid or semifluid material, lined by epithelium and supported by a connective tissue capsule.Kramer (1974) rightly defined a cyst as 'a pathological cavity having fluid, semifluid or gaseous contents and which is not created by the accumulation of pus' ${ }^{52}$ The occurrence of cysts in oral 
and maxillofacial region deserve one's attention, mainly because of the different complications that can originate, such as facial-aesthetic changes, jaw fractures, infections, and occasional neoplasia of its epithelium. These cysts can occur in the jaws, in the maxillary antrum and in the soft tissues of mouth, face, neck and salivary glands. Their incidence and epidemiological behaviour exhibits geographical variations in different regions of the world. (Table 5 and 6)

In the present study, over a period of 35years the prevalence of cysts of the orofacial region accounted to $19.08 \%$ and odontogenic cysts accounted to $16.35 \%$ of all the biopsies received in the department of Oral Pathology. These finding were consistent to that of Daley et al. ${ }^{12}$ who reported $18.20 \%$ of orofacial cysts and $17.20 \%$ of odontogenic cysts. The prevalence of orofacial cysts and odontogenic cysts in the study done by Grossman et al. ${ }^{17}$ was $15.2 \%$ and $14.75 \%$ and by Tekkesin et al. ${ }^{53}$ was $12.02 \%$ and $11.8 \%$ respectively. However in the study by Daley et al. aneurysmal bone cyst and traumatic bone cysts were not included, as they are considered as pseudocysts that fail to satisfy the definition of a cyst. In a study by Acikgoz et al. ${ }^{1}$ the prevalence of orofacial cysts and odontogenic cysts was very low accounting to $3.72 \%$ and $3.65 \%$ respectively.(Table 7 )

Of the total of 1242 cases of cysts of the orofacial region, the jaw cysts accounted to $86.71 \%$ of which $98.79 \%$ were of odontogenic origin and $1.21 \%$ was of non- odontogenic origin, cysts of the maxillary antrum was $0.32 \%$, while cysts of the soft tissues of the mouth, face,neck and salivary glands was $12.96 \%$. In the study by Daley et al. ${ }^{12}$ the cysts of the jaws accounted to $98.64 \%$, cyst of maxillary antrum $0.08 \%$ and cysts of the soft tissues of the mouth, face, neck and salivary glands $1.28 \%$. This study confirms that the prevalence of cystic lesions are common in the jaw bones and this could be due to the fact that majority of intra-bony cystic lesions occur as a result of activation of epithelial component of the developing tooth or their remnants. This type of a phenomenon of having epithelium within the bone is uncommon in bones other than the mandible and maxilla. ${ }^{54}$ The cysts of the jaws are probably the most common benign destructive bone lesions in the human maxillofacial skeleton, accounting for almost one fourth of the pathological lesions ${ }^{52}$.

Cystic lesions of the jaws can be either odontogenic or non-odontogenic, developmental, or inflammatory in origin. In the present study $38.07 \%$ of the cysts were developmental and $61.84 \%$ were inflammatory in origin. This is in general agreement with the type of cyst distribution found in large series of case studies.

From the available literature, it appears that odontogenic cysts account for between $0.8 \%$ and $45.9 \%$ of all submitted specimens. ${ }^{21}$ In our study there was $16.35 \%$ prevalence rate of odontogenic cysts and the results closely paralleled to that reported by Daley et al.17.12\% ${ }^{12}$ but was less than that reported by Happonen from Finland. ${ }^{18}$

In the present study, odontogenic cysts occurred in men more frequently than in women, this can be justified with the increased incidence of radicular cysts in men and these findings are in accordance with other reported studies in literature (Mosqueda-Taylor et al. 2002, ${ }^{35}$ Bataineh et al. 2004, ${ }^{8}$ Jones et al. 2006, ${ }^{21}$ Meningaud et al. $2006,{ }^{32}$ Varinauskas et al. $2006,{ }^{56}$ Ochsenius et al. $2007,{ }^{41}$ Prockt et al. $2008,{ }^{43}$ Avelar et al. $2009,{ }^{7}$ Sanatkhani et al. $2011,{ }^{49}$ Lawal et al. $2012^{26}$ ) but in contrast to the report by Borges et al. (2012) ${ }^{9}$ who reported increased incidence of odontogenic cysts in the female gender. Maxilla was the most commonly affected site, but the findings differ from the studies by Meningaud et al. (2006), ${ }^{32}$ Avelar et al. (2009), ${ }^{7}$ Sanatkhani et al. (2011) ${ }^{49}$ and Lawal et al. $(2012)^{26}$ where the mandible was the commonly affected site. As for the age distribution, the peak incidence of odontogenic cysts was between 21 and 30 years consistent with the findings of other studies (Ochsenius et al. 2007, ${ }^{41}$ Avelar et al. 2009, ${ }^{7}$ Borges et al. 2012 $2^{9}$ ).

Our results showed $61.84 \%$ of inflammatory cysts whereas that observed in the literature is within the range of $58.2 \%$ to $74.3 \%$ as observed in studies involving different populations. ${ }^{8,21,41}$ On the other hand, studies involving populations from Mexico demonstrated a higher frequency of developmental cysts $(55.5 \%) .{ }^{35}$ De Souza et al. postulated that the socioeconomic conditions of the population might influence the relative frequency of inflammatory and developmental OCs. ${ }^{13}$

Inflammatory jaw cysts comprise a group of lesions that arise as a result of epithelial proliferation within an inflammatory focus due to a number of causes. Radicular cysts arise from the epithelial residues in the periodontal ligament as a result of periapical periodontitis following death and necrosis of the pulp. Cysts arising in this way are found most commonly at the apices of the involved teeth, but may also be found on the lateral aspects of the roots in relation to lateral accessory root canals. ${ }^{52}$ 
Among the odontogenic cysts, inflammatory odontogenic cysts were $61.84 \%$ and radicular cyst was found to be the most frequent, representing $47.58 \%$ of all the cysts of the orofacial region and $55.55 \%$ of all the odontogenic cysts. Our results were lower than that reported by Varinauskas et al. (86.2\%), ${ }^{56}$ Tortorici et al. $(84.5 \%),{ }^{55}$ Franklin and Jones $(80 \%),{ }^{22}$ Prockt et al. $(72.5 \%),{ }^{43}$ Kochaji N et al.(78.3\%), ${ }^{24}$ Deepthi et al $(75.11 \%),{ }^{14}$ Souza LB et al. $(61.4 \%),{ }^{13}$ Daley et al. $(64.95 \%),{ }^{12}$ Grossman et al. $(61 \%),{ }^{17}$ were almost similar to that of Tekkesin et al. $(55.09 \%),{ }^{53}$ Meningaud et al. $(53.5 \%),{ }^{32}$ Jones et al. $(52.3 \%),{ }^{21}$ Niranjan et al. $(50.8 \%),{ }^{14}$ Ochsenius et al. $(50.7 \%),{ }^{41}$ and higher than Ogunlene $(21.4 \%),{ }^{42}$ Saghravanian et al. $(30.45 \%),{ }^{38}$ Ledesma- Montes et al. $(38.8 \%),{ }^{27}$ MosquedaTaylor et al.(39.9\%), ${ }^{35}$ Nakamura et al. $(41.2 \%)^{36}$ and Bataineh et al.(41.7\%). ${ }^{8}$ The high rate of radicular cysts found by Franklin and Jones ${ }^{22}$ may be explained by the fact that their study was conducted with biopsies performed by general practitioners, instead of only oral and maxillofacial surgeons. The low frequency in Nigeria $(21.4 \%){ }^{42}$ can be correlated by the joint epidemiological longitudinal dental survey by Kubatowho found $79 \%$ of the population were caries free. In studies by Daley et al. ${ }^{12}$ Kochaji et al. ${ }^{24}$ and Varinauskas et al. ${ }^{56}$ residual cysts were included under the group of radicular cyst. According to literature the most frequently affected site is anterior maxilla, ${ }^{21,41,}$ ${ }^{27}$ which is in agreement with our findings but differs from those reported by Meningaudet al. ${ }^{32}$ who reported that mandible was more frequently affected. The predominant location was maxillary anterior region could be due to the fact that anterior group of teeth are susceptible to trauma, preservation of anterior teeth even when endodontic treatment is inadequate as patients wish for aesthetics ${ }^{21}$ and high prevalence of palatal invaginations in the maxillary lateral incisors. Ochsenius et al. ${ }^{41}$ from Chile, having had the same findings stated that aesthetic factors lead people to conserve these dental tissues, and therefore, they are more likely to subject them to long-term chronic inflammatory processes, without adequate resolutive endodontic treatment. The prevalence of male gender was slightly greater than the female gender in our study which is in agreement with other authors. ${ }^{21,8,32,55}$ However, Prockt et al., ${ }^{43}$ Ochsenius et al., ${ }^{41}$ Mosqueda-Taylor et al., ${ }^{35}$ Ledesma Montes et al. ${ }^{27}$ De Souza et al. ${ }^{13}$ reported female predominance. The higher prevalence of male gender in some studies may be due to the fact that men usually have poor oral hygiene and are more susceptible to trauma than females. The cases were found in the second, third and fourth decade which are in agreement with the findings in the literature. ${ }^{8,21,41,27}$ Nakamura et al. $(41.2 \%)^{36}$ and Bataineh et al. $(41.7 \%){ }^{8}$

Quite often a radicular cyst remains behind in the jaws after removal of the offending tooth and this is referred to as a residual cyst. ${ }^{52} \mathrm{~A}$ residual cyst was found to be $5.95 \%$ of all the cysts and $6.95 \%$ of odontogenic cysts. It was the next common odontogenic cyst similar to that mentioned in the literature ${ }^{8}{ }^{21,32,35,41,27}$ Ioannidou et al. ${ }^{20}$ found it to be the second most common odontogenic cyst $(28.4 \%)$. The prevalence was higher than Prockt et al. ${ }^{43}(4.26 \%)$, Meningaud et al. ${ }^{32}(4.6 \%)$, Ledesma Montes et al. ${ }^{27}(4.9 \%)$ and almost similar to Saghravanian et al. ${ }^{38}(6.5 \%)$, Al Sheddi et al. ${ }^{3}(6.6 \%)$, Jones et al. ${ }^{21}(8 \%)$ and Tekkesin et al. ${ }^{53}(9.63 \%)$. The prevalence was lower than that reported by Ochsenius et al. ${ }^{41}(11.1 \%)$ and Acikgoz et al. ${ }^{1}(13.7 \%)$. Ledesma Montes et al. ${ }^{27}$ found that residual cysts occurred in women more frequently which differed from our finding as well as studies in the literature which showed male predominance. ${ }^{8} \cdot 21,32,35,41,43$ The maximum cases were seen in third decade followed by fourth, fifth and sixth decade alike other studies. ${ }^{8,27,41}$ The finding that patients with residual cysts are older than that of radicular cyst may be explained by the fact that they are asymptomatic and are detected months or years later because of secondary infection or as an incidental radiographic finding. ${ }^{43}$ Though both the jaws were equally affected mandibular posterior region was the common site. In study by Jones et al. and Ochsenius et al. the most common location was maxillary anterior region. ${ }^{21,41}$

A paradental cyst is an inflammatory odontogenic cyst usually occurring on the lateral root surface of a partly erupted tooth, and arising secondary to inflammation associated with pericoronitis leading to proliferation and cystic degeneration of follicular-reduced enamel epithelium. ${ }^{52}$ Only one case was reported in the present study $(0.08 \%)$. The incidence in the literature is found to range from $0.48 \%$ to $5.6 \% .^{52}$ Jones et al. on considering the no. of cases diagnosed in their study and very few case series published, suggested that these cysts are more common than what is found in the literature. ${ }^{21}$

Clinical presentation of infection at the cyst area is usually associated with acute or chronic inflammation at the cyst wall. In these cases the epithelial lining of the cyst wall may be destroyed, regardless of cyst origin, leaving the cyst wall with granulation tissue. Such cases in the present study, were clinically and radiographically diagnosed as developmental odontogenic cysts but histopathologically, due to absence of epithelial lining and inflammation, were grouped as unclassified odontogenic cyst. These lesions could not be categorized as radicular cyst since the patients did not have history of trauma nor were they associated with a non-vital tooth. Jones et al. ${ }^{21}$ also in their study 
because of a lack of clinical information stated 210 (2.9\%) cysts as unclassified owing to histopathological diagnostic difficulties in differentiating between an inflamed developmental and a true inflammatory cyst.

Odontogenic keratocysts used to be classified as odontogenic cysts arising from remnants of the dental lamina. ${ }^{52}$ In addition to their marked tendency to recur, their clinical aggressiveness, high mitotic count, and greater epithelial turnover rate indicated that they might be benign cystic tumors. ${ }^{10}$ Genetic findings of the Gorlin-Goltz syndrome (nevoid basal cell carcinoma syndrome) and of spontaneous cases of OKC led to the reclassification of these lesions. ${ }^{48}$ However in the recent WHO classification of 2017 they have been reincorporated as cystic lesions and not as neoplastic (Keratocystic Odontogenic Tumor ). ${ }^{59}$ In the present study the OKC was reported as the second most common orofacial cyst $(11.75 \%)$ and second most common odontogenic cyst $(13.72 \%)$ similar to that reported by Tekkesin et al. ${ }^{53}$, Moctezuma Bravo et al. ${ }^{33}$, Rao K et al. ${ }^{46}$ However, in other studies it is the third most common odontogenic cyst. The frequency in the present study was near parallel to that reported by Jones et al. $(11.6 \%){ }^{21} \mathrm{El}$ Gehani et al. (14.1\%), ${ }^{16}$ Ochsenius et al. $(14.3 \%),{ }^{41}$ Nakamura et al. $(9.7 \%)^{36}$ but lower than that reported by Saghravanian et al.(25\%), ${ }^{38}$ Meningaud et al.(19.1\%), ${ }^{32}$ Ledesma-Montes et al.(18.7\%) ${ }^{27}$ and higher than Tortorici et al.(1.3\%), ${ }^{55}$ Prockt et al.(3.95\%), ${ }^{43}$ Acikgoz et al.(3.3\%), ${ }^{1}$ Daley et al. $(4.88 \%),{ }^{12}$ Souza et al. $(6.4 \%){ }^{13}$ and Grossman et al. (7.2\%). ${ }^{17}$ The authors Niranjan et al., ${ }^{39}$ Lawal et al., ${ }^{26} \mathrm{Al}$ Sheddi et al. ${ }^{3}$ had excluded OKC from their study on odontogenic cysts. The majority of present cases were diagnosed in male patients between second and fourth decades of life. This is consistent with the findings mentioned in the other studies. ${ }^{35,41}$ Jones et al. reported two peaks of incidence one between the second and third decade and the other between the sixth and seventh decades. ${ }^{21} \mathrm{~A}$ study conducted by koseoglu et al. ${ }^{25}$ demonstrated higher frequency in females. The predominant location was mandibular posterior region similar to that mentioned in the literature. ${ }^{41} \mathrm{OKC}$ was found as a part of GorlinGoltz syndrome in $5.75 \%$ cases which was almost similar to that reported by Grossman et al. $(3.85 \%)^{17}$ whereas Ochsenius et al. ${ }^{41}$ reported $15.4 \%$ association with the syndrome.

Orthokeratinized odontogenic cysts, a rare developmental jaw cyst that has been considered as a variant of the keratocystic odontogenic tumor are reported separately as these have been recognized as a new entity in the recent past, and is included as a separate entity by the WHO classification. ${ }^{59}$ Due to the histopathology as well as the behavioral difference it is justifiable to label it as a separate entity. Since we started using this nomenclature recently and because of the rarity of the lesion only 3 cases were reported. The clinical findings related to age, gender and location was in accordance with previous literature by MacDonald-Jankowski ${ }^{30}$ and Dong et al. ${ }^{15}$

A dentigerous cyst is one that encloses the crown of an unerupted tooth by expansion of its follicle, and is attached to its neck. ${ }^{52}$ Most studies reported that they are second most prevalent odontogenic cysts. ${ }^{8,21,27,32,35,41,43,56}$ However, in the present study it was the third most frequent odontogenic cysts (11.84\%) and fourth most frequent orofacial cysts. In the study by Tekkesinet al. ${ }^{53}$ the dentigerous cyst was the third most frequent odontogenic cyst $(10.57 \%)$. The greater number of cysts occurred in males and was parallel to the findings in the literature. ${ }^{8,21,27,32,35,41}$ Prockt et al. reported slight female predominance. ${ }^{43}$ The posterior mandible was most frequently affected site followed by anterior maxilla as reported in the literature. ${ }^{8,21}, 37,4143$ Such prevalence may be explained by the large no. of impacted third molars and maxillary canines as well as supernumerary teeth i.e. mesiodens. A study by Waldron et al. $1995^{58}$ showed upper third molar to be the most prevalent site. Most cysts occurred in second decade of life similar to studies conducted by the other authors. ${ }^{8,27,41,43}$ Jones et al. ${ }^{21}$ found a frequency peak in the fifth and sixth decades of life which differs from the findings in the present study. Some studies suggest that dentigerous cyst may have an inflammatory origin. It has been reported that inflammation progressing from the root apex of deciduous tooth brings about development of the Dentigerous cyst around the unerupted permanent tooth. ${ }^{37}$ In the present study almost half of the cysts were associated with secondary infection.

Over the years since its first description, it has become clear that the calcifying odontogenic cyst (COC) has a number of variants; including features of a benign odontogenic tumour.COC represented $0.48 \%$ of the orofacial cysts and $0.56 \%$ of the odontogenic cysts. Jones et al. ${ }^{21}$ reported the prevalence of $0.3 \%$, Tekkesin et al. ${ }^{53}(0.66 \%)$, Niranjan et al..$^{39}(0.8 \%)$, Grossman et al. ${ }^{17}(1 \%)$, Souza et al. ${ }^{35}(2.8 \%)$, and Saghravanian et al. ${ }^{38}(7.5 \%)$. Jones et al ${ }^{21}$ found predilection for males with an approximately equal distribution for each decade and an age range from 5-79 years. But Souza et al. ${ }^{13}$ found female predominance and equal involvement of both jaws. While Tekessin et al. ${ }^{53}$ although found female predominance but maxilla was commonly affected than mandible.In the present study, equal gender distribution and occurrence in second and third decade with maxilla being commonly affected than mandible was found. 
The designation 'lateral periodontal cyst' is confined to those cysts that occur in the lateral periodontal position and in which an inflammatory aetiology and a diagnosis of collateral OKC have been excluded on clinical and histological grounds. ${ }^{52}$ Studies in the literature found a frequency of $0.2-8 \%$ of all odontogenic cysts ${ }^{5,8,21,32,3541}$ and only $2(0.16 \%)$ cases which represented $0.18 \%$ of odontogenic cysts were found in our study. A predilection for male sex $5,8,21,32,3541$, and the premolar region is found in the literature. ${ }^{8,41}$

Glandular odontogenic cyst(GOC) has acquired numerous synonyms including sialo-odontogenic cyst, a term first proposed by Padyachee and van Wyk in 1987 and polymorphous odontogenic cyst. ${ }^{19,21}$ These lesions predominantly occur in the fifth decade, with a predilection for the anterior mandible and appear to affect male patients. ${ }^{21} \mathrm{GOC}$ was reported in 2 cases $(0.16 \%)$, one male and one female aged 44 and 20 years respectively. In both the cases site involved was mandibular posterior region.

Among the non-odontogenic cysts, the nasolabial cyst occurs outside the bone in the nasolabial folds below the alae nasi. It is traditionally regarded as a jaw cyst although strictly speaking it should be classified as a soft tissue cyst. As the alveolus is not involved, the term nasolabial is preferred to nasoalveolar cyst. ${ }^{52}$ There are a few studies that investigated odontogenic and non-odontogenic developmental cysts together. We found that nasolabial cyst $(0.56 \%)$ was the most frequent non odontogenic cyst followed by nasopalatine duct cyst $(0.4 \%)$.In the study by Grossman et al. $^{17}$ and Daley et al. ${ }^{12}$ the nasolabial and nasopalatine cyst were found to be $1 \%, 2.2 \%$ and $0.09,4 \%$ respectively. Tekessin et al. ${ }^{53}$ reported $1.3 \%$ prevalence of nasopalatine cyst. Lopes Rocha et al. ${ }^{29}$ reported $0.29 \%$ prevalence of nasolabial cyst and found female predominance with mean age of occurrence in fourth decade. In the present study almost equal gender distribution and predominance in third decade was noted. Nasopalatine cyst was predominantly found in males with mean age of occurrence in fourth decade which is similar to the finding of Vasconcelas et al. ${ }^{57}$

Cyst of maxillary antrum consisted of post-operative maxillary cyst $(0.24 \%)$ and mucocele of maxillary antrum $(0.08 \%)$.The postoperative maxillary cyst is fairly commonly encountered in Japan but appears to be a rare lesion in most other parts of the world. Its name is derived from the fact that it is a delayed complication arising years after surgery involving the maxillary sinus. ${ }^{52}$ The prevalence reported by Daley et al. ${ }^{12}$ was $1.5 \%$. A true antral mucocoele completely fills the sinus and is caused by blockage of the ostium, which may be secondary to inflammatory changes associated with chronic rhinosinusitis. The lesion is a true cyst filled with mucus and lined by the mucoperiosteum of the involved sinus. ${ }^{52}$

Mucous extravasation cysts and mucous retention cysts are often referred to collectively as mucoceles. Mucoceles of the mouth are very common. Their true incidence is difficult to determine as many patients endure them without seeking treatment, and of those diagnosed a large number are not surgically excised and do not reach a pathology department. The great majority of mucoceles are found in the lower lip. ${ }^{52}$ Similar findings were seen in our study with male predominance and lower lip being commonly affected. The peak frequency was seen in third followed by second decade as seen in the literature. ${ }^{52}$

Dermoid and epidermoid cysts may occur on the floor of the mouth. Dermoid cysts are developmental cysts arising from entrapped midline ectodermal tissue lined by epidermis with skin appendages present in the fibrous wall. Epidermoid cysts are similar cysts lined by epidermis, but without appendages. The terms sebaceous cyst is used clinically and no longer have any pathological connotation. ${ }^{52}$ Al-Khateeb et al. ${ }^{4}$ in 2009 conducted a retrospective study of cutaneous cysts of head and neck in 488 patients finding the most frequent lesion to be epidermoid cysts $(49 \%)$, followed by pilar cysts $(27 \%)$ and dermoid cyst $(22 \%)$ In the Sheffield series, Jones and Franklin (2006a) 22 found that only 19 dermoid cysts had been reported from a total of 44007 adult head and neck specimens over a 30year period i.e. $0.04 \%$.In the present study the prevalence was higher $0.48 \%$ and all the cases were found in male patients. Longo et al. (2003) ${ }^{28}$ reported male to female ratio of 3:1 however Al Khateebet al. ${ }^{4}$ found no gender difference. Regarding the location of DC, the periorbital area is the most commonly affected area as mentioned by Pryor et al. ${ }^{44}$ and Al Khateeb et al. ${ }^{4}$ The intraoral sites are floor of the mouth, tongue, lips, buccal mucosa and jaw bones. ${ }^{4,44}$ In the present study it involved infra and supra orbital region, posterior mandibular region of the face and lower lip. The peak age of distribution with dermoid cyst was first decade as observed by Al Khateebet al. ${ }^{4}$ however in present study it was observed in third decade followed by first and second decade.

Epidermoid cysts was found by Al Khateebet al. ${ }^{4}$ to be the most frequent lesion in neck $(68 \%)$, cheeks $(77 \%)$, Preauricular area $(70 \%)$ and nasal area $(55 \%)$ and peaked at the third decade. In the present study one case each of 
epidermoid cyst was found in third, fourth, fifth, sixth and eight decade and buccal mucosa was the most common site involved.

As only one case of traumatic bone cyst, cysticercus cellulosae were found in our study, we are left with little scope for definitive comparative analysis.

The lining of odontogenic cysts may show a potential for neoplastic transformation to non - odontogenic malignancies like squamous cell carcinoma and mucoepidermoid carcinoma and odontogenic tumors like Ameloblastoma and Adenomatoid odontogenic tumor (AOT). ${ }^{31}$ There is un-certainty whether the lining of an associated cyst represents a true odontogenic cyst, a cystic change in a odontogenic tumour or represents a distinct entity. ${ }^{39,50}$ In the present study 25 cases showed ameloblastomatous transformation, one case each showed malignant transformation, mucoepidermoid carcinoma transformation, OKC with ameloblastic fibroodontome and squamous odontogenic tumor like proliferation in residual cyst.( Table: 4)

The cyst of the orofacial region specifically the odontogenic cysts, may be clinically misdiagnosed as both clinical presentation and radiological signs are similar for many of these cysts. Therefore, knowledge on the incidence of odontogenic cysts as well as their common sites of presentation and age distribution may help practitioners to determine a likely clinical diagnosis. The correct diagnosis of cyst is important as some of these lesions are known to have an aggressive behaviour and propensity to recur. Therefore, all surgically removed tissue should be submitted for histological diagnosis to ensure appropriate treatment is provided.

In our study we found that around $50 \%$ of the cases were radicular cyst, associated with caries or trauma . These can be prevented to a greater extent if awareness is created among the general public and proper patient counselling and follow -up.

Drawbacks of retrospective studies and recommendations to resolve the same

- Some records sent together with the biopsy material may be incomplete impairing the histopathologic diagnosis and, consequently, the execution of retrospective studies.

- A systematic approach of classification may not be usually followed, placing the lesions under general broad nomenclature.

- The lining epithelium in some cysts which may be lost due to primary or secondary inflammation or iatrogenic causes related with surgical procedures or during tissue processing. In such cases it becomes very difficult to give a definitive diagnosis, sometimes clinicopathologic correlation can be done while sometimes these cysts are just diagnosed as odontogenic cysts or infected dental cysts

\section{Recommendations:-}

- Clinicians should be motivated to put in all the details observed during the examination of the lesion along with a proper case history.

- $\quad$ Every institute should follow a systematic nomenclature while diagnosing the lesions which will help in long term surveys and also help in understanding the need of the hour to deal with the frequently encountered lesion.

- Compilation of data from various institutes.

- Standardization in collecting and maintaining the data for further analysis

- Development of computerized database for maintenance of the records.

These will help in the maintenance of precise data and in turn provide a larger data for comparative studies based on archival materials. This would further lead to better understanding, diagnosis and treatment of patients. 
Figure 1:- 35 Year Distribution of 1242 cases of cysts of orofacial region (1981-2015)

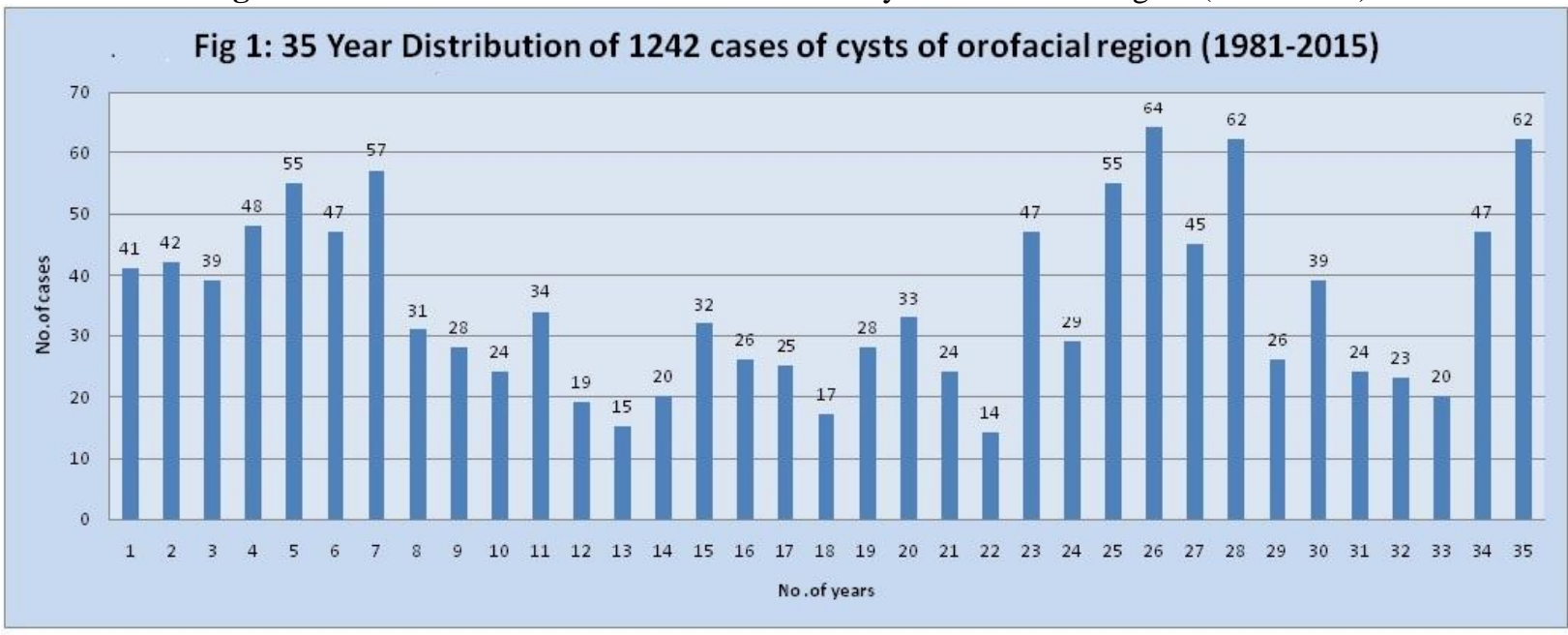

Tables 1:- Distribution of cystic lesions according to classification of Shear 2007

\begin{tabular}{|c|c|c|c|c|c|}
\hline \multicolumn{4}{|c|}{ Cyst of the jaws } & $\begin{array}{l}\text { Cyst associated } \\
\text { with Maxillary } \\
\text { Antrum }\end{array}$ & $\begin{array}{l}\text { Cysts of the soft } \\
\text { tissue of the } \\
\text { mouth, face, } \\
\text { neck and salivary } \\
\text { gland }\end{array}$ \\
\hline \multicolumn{3}{|l|}{ Epithelial-lined } & $\begin{array}{l}\text { Non Epithelial- } \\
\text { lined }\end{array}$ & \multirow[t]{4}{*}{4} & \multirow[t]{4}{*}{$160+1(161)$} \\
\hline \multicolumn{2}{|c|}{ Developmental } & Inflammatory & \multirow[t]{3}{*}{1} & & \\
\hline Odontogenic & $\begin{array}{l}\text { Non- } \\
\text { Odontogenic }\end{array}$ & \multirow[t]{2}{*}{666} & & & \\
\hline 398 & 12 & & & & \\
\hline \multicolumn{4}{|l|}{$1077(86.71 \%)$} & $4(00.32 \%)$ & $161(12.96 \%)$ \\
\hline
\end{tabular}

Tables 2:- Distribution of all cysts according to histopathological diagnosis and gender.

\begin{tabular}{|l|l|l|l|l|l|l|}
\hline Type & No. & \% & Male & Female & NM & M:F \\
\hline Radicular Cyst & 591 & 47.58 & 348 & 227 & 16 & $1.53: 1$ \\
\hline $\begin{array}{l}\text { OdontogenicKeratocyst / } \\
\text { Keratocystic Odontogenic Tumor }\end{array}$ & 146 & 11.75 & 90 & 49 & 7 & $1.84: 1$ \\
\hline Mucocele & 145 & 11.67 & 104 & 40 & 1 & $2.60: 1$ \\
\hline Dentigerous Cyst & 126 & 10.14 & 92 & 34 & - & $2.70: 1$ \\
\hline Unclassifiable Odontogenic Cyst & 113 & 09.09 & 74 & 39 & - & $1.90: 1$ \\
\hline Residual cyst & 074 & 05.95 & 43 & 31 & - & $1.39: 1$ \\
\hline Nasolabial cyst & 007 & 00.56 & 4 & 3 & - & $1.33: 1$ \\
\hline Dermoid cyst & 006 & 00.48 & 6 & 0 & - & - \\
\hline Calcifying Odontogenic Cyst & 006 & 00.48 & 3 & 3 & - & $1.00: 1$ \\
\hline Epidermoid cyst & 005 & 00.40 & 4 & 1 & - & $4.00: 1$ \\
\hline Nasopalatine cyst & 005 & 00.40 & 4 & 1 & - & $4.00: 1$ \\
\hline OrthokeratinizedOdontogenic Cyst & 003 & 00.24 & 1 & 2 & - & $0.50: 1$ \\
\hline Sebaceous cyst & 003 & 00.24 & 3 & 0 & - & - \\
\hline Surgical Ciliated Cyst of Maxilla & 003 & 00.24 & 2 & 1 & - & $2.00: 1$ \\
\hline Glandular odontogenic cyst & 002 & 00.16 & 1 & 1 & - & $1.00: 1$ \\
\hline Lateral Periodontal Cyst & 002 & 00.16 & 1 & 1 & - & $1.00: 1$ \\
\hline Lymphoepithelial Cyst (Branchial) & 001 & 00.08 & 1 & 0 & - & - \\
\hline Mucocele of Maxillary Antrum & 001 & 00.08 & 0 & 1 & - & - \\
\hline Paradental cyst & 001 & 00.08 & 1 & 0 & - & - \\
\hline
\end{tabular}




\begin{tabular}{|l|l|l|l|l|l|l|}
\hline Traumatic bone cyst & 001 & 00.08 & 0 & 1 & - & - \\
\hline Cysticercuscellulosae & 001 & 00.08 & 1 & 0 & - & - \\
\hline Total & $\mathbf{1 2 4 2}$ & $\mathbf{1 0 0 \%}$ & $\mathbf{7 8 4}$ & $\mathbf{4 3 4}$ & $\mathbf{2 4}$ & $\mathbf{1 . 8 1 : 1}$ \\
\hline
\end{tabular}

Tables 3:- Age-Wise distribution of Oro-facial cyst.

\begin{tabular}{|c|c|c|c|c|c|c|c|c|c|c|}
\hline Type & $1-10$ & $11-20$ & $21-30$ & $31-40$ & $41-50$ & $51-60$ & $61-70$ & $71-80$ & $81-90$ & NM \\
\hline Radicular Cyst & 22 & 138 & 200 & 100 & 50 & 31 & 13 & 04 & 01 & 32 \\
\hline Mucocele & 06 & 44 & 58 & 16 & 13 & 04 & 00 & 01 & 00 & 03 \\
\hline OdontogenicKeratocyst & 02 & 44 & 34 & 31 & 10 & 08 & 06 & 00 & 00 & 11 \\
\hline Dentigerous Cyst & 21 & 45 & 31 & 11 & 08 & 04 & 02 & 00 & 00 & 04 \\
\hline $\begin{array}{l}\text { Unclassifiable } \\
\text { Odontogenic Cyst }\end{array}$ & 11 & 26 & 38 & 19 & 08 & 07 & 03 & 00 & 00 & 01 \\
\hline Residual cyst & 00 & 10 & 22 & 18 & 10 & 09 & 01 & 01 & 00 & 03 \\
\hline Nasolabial cyst & 00 & 00 & 04 & 01 & 01 & 01 & 00 & 00 & 00 & 00 \\
\hline Dermoid cyst & 01 & 01 & 03 & 00 & 00 & 00 & 00 & 01 & 00 & 00 \\
\hline $\begin{array}{l}\text { Calcifying Odontogenic } \\
\text { Cyst }\end{array}$ & 00 & 03 & 03 & 00 & 00 & 00 & 00 & 00 & 00 & 00 \\
\hline Epidermoid cyst & 00 & 00 & 01 & 01 & 01 & 01 & 00 & 01 & 00 & 00 \\
\hline Nasopalatine cyst & 00 & 01 & 01 & 02 & 00 & 01 & 00 & 00 & 00 & 00 \\
\hline $\begin{array}{l}\text { Orthokeratinized } \\
\text { Odontogenic Cyst }\end{array}$ & 00 & 00 & 01 & 01 & 01 & 00 & 00 & 00 & 00 & 00 \\
\hline Sebaceous cyst & 00 & 01 & 00 & 01 & 01 & 00 & 00 & 00 & 00 & 00 \\
\hline $\begin{array}{l}\text { Post-operative maxillary } \\
\text { cyst }\end{array}$ & 00 & 00 & 00 & 01 & 02 & 00 & 00 & 00 & 00 & 00 \\
\hline $\begin{array}{l}\text { Glandular odontogenic } \\
\text { cyst }\end{array}$ & 00 & 01 & 00 & 00 & 01 & 00 & 00 & 00 & 00 & 00 \\
\hline Lateral Periodontal Cyst & 00 & 00 & 01 & 00 & 00 & 01 & 00 & 00 & 00 & 00 \\
\hline $\begin{array}{l}\text { Lymphoepithelial Cyst } \\
\text { (Branchial) }\end{array}$ & 00 & 00 & 00 & 00 & 00 & 01 & 00 & 00 & 00 & 00 \\
\hline $\begin{array}{l}\text { Mucocele of Maxillary } \\
\text { Antrum }\end{array}$ & 00 & 00 & 00 & 01 & 00 & 00 & 00 & 00 & 00 & 00 \\
\hline Paradental cyst & 00 & 00 & 00 & 01 & 00 & 00 & 00 & 00 & 00 & 00 \\
\hline Traumatic bone cyst & 00 & 01 & 00 & 00 & 00 & 00 & 00 & 00 & 00 & 00 \\
\hline Cysticercus cellulosae & 00 & 01 & 00 & 00 & 00 & 00 & 00 & 00 & 00 & 00 \\
\hline Total & 63 & 316 & 397 & 204 & 106 & 68 & 25 & 8 & 1 & 54 \\
\hline
\end{tabular}

Tables 4:- Complications associated with Odontogenic cysts.

\begin{tabular}{|c|c|c|c|c|}
\hline Type & No. & Male & Female & $\mathbf{M : F}$ \\
\hline Cyst undergoing ameloblastomatouschanges & 25 & 13 & 12 & 1.08:1 \\
\hline Odontogenic cyst with mucoepidermoid carcinoma transformation & 1 & 0 & 1 & - \\
\hline Odontogenic keratocyst with malignant transformation & 1 & 1 & 0 & - \\
\hline Odontogenic keratocyst with ameloblastic fibroodontome & 1 & 0 & 1 & - \\
\hline Squamous odontogenic tumor like proliferation in Residual cyst & 1 & 1 & 0 & - \\
\hline Total & 29 & 15 & 14 & 1.07:1 \\
\hline
\end{tabular}

Tables 5:- Indian Studies on Odontogenic Cyst.

\begin{tabular}{|c|c|c|c|c|c|c|c|c|}
\hline Author & $\begin{array}{l}\text { Present } \\
\text { Study }\end{array}$ & $\begin{array}{l}\text { Rao } \mathrm{K} \text {, } \\
\text { et al. }^{35}\end{array}$ & $\begin{array}{l}\text { Ravi } \\
\text { Kumar } \\
\mathrm{H}, \quad \text { et } \\
\text { al. }^{51}\end{array}$ & $\begin{array}{l}\text { Selvam } \\
\text { ani M, } \\
\text { et al. }\end{array}$ & $\begin{array}{l}\text { Deepthi } \\
\text { PV et } \\
\text { al. }^{23}\end{array}$ & $\begin{array}{l}\text { Moham } \\
\text { mad SD } \\
\text { et al. }\end{array}$ & $\begin{array}{l}\text { Niranjan } \\
\mathrm{KC} \text { et } \\
\text { al. }^{24}\end{array}$ & $\begin{array}{l}\text { Ramacha } \\
\text { ndra P et } \\
\text { al. }^{54}\end{array}$ \\
\hline Place & $\begin{array}{l}\text { Mumbai } \\
\text { India }\end{array}$ & $\begin{array}{l}\text { Bangalor } \\
\text { e, India }\end{array}$ & $\begin{array}{l}\text { Davange } \\
\text { re, } \\
\text { Karnatak } \\
\text { a, India }\end{array}$ & $\begin{array}{l}\text { Davang } \\
\text { ere, } \\
\text { Karnata } \\
\text { ka, }\end{array}$ & $\begin{array}{l}\text { South } \\
\text { Kerala, } \\
\text { India }\end{array}$ & $\begin{array}{l}\text { UP, } \\
\text { India }\end{array}$ & $\begin{array}{l}\text { Dharwad } \\
\text { Karnatak } \\
\text { a, India }\end{array}$ & $\begin{array}{l}\text { Bangalor } \\
\text { e, India }\end{array}$ \\
\hline
\end{tabular}




\begin{tabular}{|c|c|c|c|c|c|c|c|c|}
\hline & & & & India & & & & \\
\hline Duration & $\begin{array}{l}1981- \\
2015\end{array}$ & $\begin{array}{l}2006- \\
2010\end{array}$ & $\begin{array}{l}2009- \\
2012\end{array}$ & $\begin{array}{l}2001- \\
2010\end{array}$ & $\begin{array}{l}1998- \\
2012\end{array}$ & $\begin{array}{l}2005- \\
2013\end{array}$ & $\begin{array}{l}1989- \\
2008\end{array}$ & $\begin{array}{l}2005- \\
2010\end{array}$ \\
\hline Years & 35 & 4 & 3 & 10 & 14 & 8 & 20 & 5 \\
\hline Study & $\begin{array}{l}\begin{array}{l}\text { Oro- } \\
\text { facial } \\
\text { cysts }\end{array} \\
\mathbf{1 2 4 2 / 6 5 0} \\
9 \\
(19.08 \% \\
)\end{array}$ & $\begin{array}{l}\text { Odontog } \\
\text { enic } \\
\text { cysts }\end{array}$ & $\begin{array}{l}\text { Odontog } \\
\text { enic } \\
\text { cysts }\end{array}$ & $\begin{array}{l}\text { Jaw } \\
\text { cysts } \\
194 / 227 \\
5 \\
(8.5 \%)\end{array}$ & $\begin{array}{l}\begin{array}{l}\text { Odontog } \\
\text { enic }\end{array} \\
\text { lesions } \\
1177 / 71 \\
17 \\
(16.53 \% \\
)\end{array}$ & $\begin{array}{l}\begin{array}{l}\text { Odont } \\
\text { genic }\end{array} \\
\text { and } \\
\text { Non- } \\
\text { odontog } \\
\text { enic } \\
\text { cysts } \\
279 / 190 \\
0 \\
(14.68 \% \\
)\end{array}$ & $\begin{array}{l}\text { Odontog } \\
\text { enic } \\
\text { cysts and } \\
\text { tumors } \\
771 / 608 \\
2 \\
(12.67 \% \\
)\end{array}$ & $\begin{array}{l}\text { Odontoge } \\
\text { nic and } \\
\text { Non- } \\
\text { odontoge } \\
\text { nic cysts } \\
252\end{array}$ \\
\hline Odontogenic cysts & $\begin{array}{l}1064 / 650 \\
9 \\
(16.34 \% \\
)\end{array}$ & $\begin{array}{l}100 / 809 \\
(12.36 \% \\
)\end{array}$ & 120 & $\begin{array}{l}153 / 227 \\
5 \\
(6.7 \%)\end{array}$ & $\begin{array}{l}872 / 711 \\
7 \\
12.25 \%\end{array}$ & $\begin{array}{l}270 / 190 \\
0 \\
(14.21 \% \\
)\end{array}$ & $\begin{array}{l}630 / 608 \\
2 \\
(10.36 \% \\
)\end{array}$ & 201 \\
\hline Radicular Cyst & $\begin{array}{l}591(55.5 \\
4 \%)\end{array}$ & $\begin{array}{l}52 \\
(52 \%)\end{array}$ & $60(50 \%)$ & $\begin{array}{l}106(69 . \\
3 \%)\end{array}$ & $\begin{array}{l}655 \\
(75.11 \% \\
)\end{array}$ & $\begin{array}{l}167(61 . \\
8 \%)\end{array}$ & $\begin{array}{l}320(50.8 \\
\%)\end{array}$ & $\begin{array}{l}101(50.2 \\
5 \%)\end{array}$ \\
\hline Residual Cyst & $\begin{array}{l}74(6.95 \\
\%)\end{array}$ & $9(9 \%)$ & $8(6.7 \%)$ & $5(3.3 \%)$ & $\begin{array}{l}44 \\
(5.02 \%)\end{array}$ & - & $\begin{array}{l}7(1.11 \% \\
)\end{array}$ & - \\
\hline Paradental Cyst & $1(0.09 \%$ & - & - & - & - & - & - & - \\
\hline $\begin{array}{l}\text { OdontogenicKeratoc } \\
\text { yst (OKC) }\end{array}$ & $\begin{array}{l}146(13.7 \\
2 \%)\end{array}$ & $20(20 \%)$ & $8(6.7 \%)$ & $8(5.2 \%)$ & $\begin{array}{l}\text { OKC } \\
\text { under } \\
\text { Odontog } \\
\text { enic } \\
\text { tumors }\end{array}$ & $\begin{array}{l}21 \\
(7.7 \%)\end{array}$ & $\begin{array}{l}\text { OKC } \\
\text { under } \\
\text { Odontog } \\
\text { enic } \\
\text { tumors }\end{array}$ & $\begin{array}{l}55(27.36 \\
\%)\end{array}$ \\
\hline Dentigerous Cyst & $\begin{array}{l}126 \\
(11.84 \% \\
\end{array}$ & $19(19 \%)$ & $\begin{array}{l}40(33.3 \\
\%)\end{array}$ & $\begin{array}{l}31(20.3 \\
\%)\end{array}$ & $\begin{array}{l}150 \\
(17.2 \%)\end{array}$ & $\begin{array}{l}67 \\
(24.8 \%)\end{array}$ & $\begin{array}{l}65 \\
(10.32 \% \\
)\end{array}$ & $\begin{array}{l}45(22.39 \\
\%)\end{array}$ \\
\hline $\begin{array}{l}\text { Lateral Periodontal } \\
\text { Cyst }\end{array}$ & $\begin{array}{l}02(0.18 \\
\%)\end{array}$ & - & - & $\begin{array}{l}1(0.65 \% \\
)\end{array}$ & $\begin{array}{l}0 \\
(1.03 \%)\end{array}$ & - & $2(0.32 \%$ & - \\
\hline Gingival Cyst & - & - & - & $1(0.65 \%$ & - & - & & - \\
\hline $\begin{array}{l}\text { Glandular } \\
\text { odontogenic cyst }\end{array}$ & $\begin{array}{l}002(0.18 \\
\%)\end{array}$ & - & - & - & - & - & $\begin{array}{l}1(0.16 \% \\
)\end{array}$ & - \\
\hline $\begin{array}{l}\text { Calcifying } \\
\text { Odontogenic Cyst }\end{array}$ & $\begin{array}{l}006(0.56 \\
\%)\end{array}$ & - & $\begin{array}{l}4(3.33 \% \\
)\end{array}$ & - & - & - & $5(0.8 \%)$ & - \\
\hline $\begin{array}{l}\text { BotyroidOdontogeni } \\
\text { c Cyst }\end{array}$ & - & - & - & $\begin{array}{l}1(0.65 \% \\
)\end{array}$ & - & - & - & - \\
\hline $\begin{array}{l}\text { Orthokeratinizedodo } \\
\text { ntogenic cyst }\end{array}$ & $\begin{array}{l}003(0.29 \\
\%)\end{array}$ & - & - & - & - & - & $\begin{array}{l}37 \\
(5.87 \%)\end{array}$ & - \\
\hline $\begin{array}{l}\text { Unclassifiable } \\
\text { Odontogenic Cyst }\end{array}$ & $\begin{array}{l}113(10.6 \\
2 \%)\end{array}$ & - & - & - & $\begin{array}{l}14 \\
(1.61 \%)\end{array}$ & - & $\begin{array}{l}193 \\
(30.63 \% \\
\end{array}$ & - \\
\hline
\end{tabular}

Tables 6:- Comparative incidence of odontogenic cysts in different published studies.

\begin{tabular}{|c|c|c|c|c|c|c|c|c|c|c|c|c|c|c|c|c|c|c|}
\hline $\begin{array}{l}\text { Aut } \\
\text { hor }\end{array}$ & $\begin{array}{l}\text { Co } \\
\text { un } \\
\text { tr } \\
\text { y }\end{array}$ & $\begin{array}{l}\text { Du } \\
\text { rat } \\
\text { ion }\end{array}$ & $\begin{array}{l}\mathbf{Y} \\
\mathbf{r} \\
\text { S. }\end{array}$ & $\begin{array}{l}T \\
\text { ot } \\
\text { al } \\
\text { B }\end{array}$ & $\begin{array}{l}\text { To } \\
\text { tal } \\
\text { no } \\
\text { O }\end{array}$ & RC & $\begin{array}{l}\text { Re } \\
\text { sC }\end{array}$ & PC & DC & $\begin{array}{l}\text { O } \\
\text { KC }\end{array}$ & $\begin{array}{l}\mathbf{L P} \\
\mathbf{C}\end{array}$ & $\begin{array}{l}\mathbf{E} \\
\mathbf{C}\end{array}$ & G & $\begin{array}{l}\text { G } \\
\text { OC }\end{array}$ & $\begin{array}{l}\text { CO } \\
\text { C }\end{array}$ & $\begin{array}{l}\text { B } \\
\mathbf{O} \\
\mathbf{C}\end{array}$ & $\begin{array}{l}\mathbf{O} \\
\text { OC }\end{array}$ & $\begin{array}{l}\text { UO } \\
\mathbf{C}\end{array}$ \\
\hline
\end{tabular}




\begin{tabular}{|c|c|c|c|c|c|c|c|c|c|c|c|c|c|c|c|c|c|c|}
\hline & & & & & $\mathbf{C}$ & & & & & & & & & & & & & \\
\hline $\begin{array}{l}\text { Souz } \\
\text { a LB } \\
\text { et } \\
\text { al. }{ }^{19}\end{array}$ & $\begin{array}{l}\mathrm{Br} \\
\text { azi } \\
1\end{array}$ & $\begin{array}{l}19 \\
70- \\
20 \\
07\end{array}$ & $\begin{array}{l}3 \\
7\end{array}$ & $\begin{array}{l}9 \\
2 \\
1 \\
6 \\
\end{array}$ & $\begin{array}{l}10 \\
19 \\
(11 \\
\%)\end{array}$ & $\begin{array}{l}626 \\
(61 . \\
4 \% \\
)\end{array}$ & $\begin{array}{l}50 \\
(4 . \\
9 \\
\%) \\
\end{array}$ & $\begin{array}{l}17 \\
(1 . \\
7 \% \\
)\end{array}$ & $\begin{array}{l}205 \\
(20 . \\
1 \% \\
)\end{array}$ & $\begin{array}{l}65 \\
(6 . \\
4 \% \\
)\end{array}$ & $\begin{array}{l}12 \\
(1 . \\
2 \% \\
)\end{array}$ & $\begin{array}{l}3 \\
(0 . \\
3 \\
\%)\end{array}$ & $\begin{array}{l}\text { 1-I } \\
(0 . \\
1 \\
\%)\end{array}$ & $\begin{array}{l}2 \\
(0 . \\
2 \% \\
)\end{array}$ & $\begin{array}{l}29 \\
(2 . \\
8 \% \\
)\end{array}$ & $\begin{array}{l}5 \\
(0 . \\
5 \\
\%)\end{array}$ & $\begin{array}{l}4 \\
(0 . \\
4 \% \\
)\end{array}$ & - \\
\hline $\begin{array}{l}\text { Sagh } \\
\text { rava } \\
\text { nian } \\
\text { et } \\
\text { al. }^{26}\end{array}$ & $\begin{array}{l}\text { Ira } \\
\mathrm{n}\end{array}$ & $\begin{array}{l}19 \\
71- \\
20 \\
11\end{array}$ & $\begin{array}{l}4 \\
0\end{array}$ & $\begin{array}{l}1 \\
0 \\
1 \\
6 \\
5\end{array}$ & $\begin{array}{l}11 \\
89 \\
(11 \\
.7 \\
\%)\end{array}$ & $\begin{array}{l}362 \\
(30 . \\
45 \\
\%)\end{array}$ & $\begin{array}{l}77 \\
(6 . \\
5 \\
\%)\end{array}$ & $\begin{array}{l}9(0 \\
.75 \\
\%)\end{array}$ & $\begin{array}{l}319 \\
(26 . \\
8 \% \\
)\end{array}$ & $\begin{array}{l}298 \\
(25 \\
\%)\end{array}$ & $\begin{array}{l}9(0 \\
.75 \\
\%)\end{array}$ & $\begin{array}{l}8( \\
0.7 \\
\%)\end{array}$ & $\begin{array}{l}1( \\
0.1 \\
\%) \\
\text { I }\end{array}$ & $\begin{array}{l}10( \\
0.8 \\
5 \% \\
)\end{array}$ & $\begin{array}{l}89( \\
7.5 \\
\%)\end{array}$ & $\begin{array}{l}3( \\
0.2 \\
5 \\
\%)\end{array}$ & $\begin{array}{l}4(0 \\
.35 \\
\%)\end{array}$ & - \\
\hline $\begin{array}{l}\text { Jone } \\
\text { s AV } \\
\text { et } \\
\text { al. }{ }^{7}\end{array}$ & $\begin{array}{l}\mathrm{Br} \\
\text { ita } \\
\text { in }\end{array}$ & $\begin{array}{l}19 \\
75- \\
20 \\
04\end{array}$ & $\begin{array}{l}2 \\
9\end{array}$ & $\begin{array}{l}5 \\
5 \\
4 \\
4 \\
6\end{array}$ & $\begin{array}{l}71 \\
21 \\
(12 \\
.8 \\
\%)\end{array}$ & $\begin{array}{l}372 \\
4 \\
(52 . \\
3 \% \\
)\end{array}$ & $\begin{array}{l}57 \\
3 \\
(8 \\
\%)\end{array}$ & $\begin{array}{l}402 \\
(5 . \\
6 \% \\
)\end{array}$ & $\begin{array}{l}129 \\
2 \\
(18 . \\
1 \% \\
)\end{array}$ & $\begin{array}{l}828 \\
(11 \\
.6 \\
\%)\end{array}$ & $\begin{array}{l}28 \\
(0 . \\
4 \% \\
)\end{array}$ & $\begin{array}{l}15 \\
(0 . \\
2 \\
\%)\end{array}$ & $\begin{array}{l}16 \\
-\mathrm{A} \\
(0 . \\
2 \\
\%) \\
1-\mathrm{I} \\
(0 . \\
01 \\
\%)\end{array}$ & $\begin{array}{l}11 \\
(0 . \\
2 \% \\
)\end{array}$ & $\begin{array}{l}21 \\
(0 . \\
3 \% \\
)\end{array}$ & - & - & $\begin{array}{l}210 \\
(2.9 \\
\%)\end{array}$ \\
\hline $\begin{array}{l}\text { Ochs } \\
\text { enius } \\
\text { G et } \\
\text { al. }{ }^{13}\end{array}$ & $\begin{array}{l}\text { Ch } \\
\text { ile }\end{array}$ & $\begin{array}{l}19 \\
76- \\
20 \\
04\end{array}$ & $\begin{array}{l}2 \\
8\end{array}$ & $\begin{array}{l}2 \\
9 \\
3 \\
6 \\
4\end{array}$ & $\begin{array}{l}29 \\
44 \\
(10 \\
\%)\end{array}$ & $\begin{array}{l}1,4 \\
94 \\
(50 . \\
7 \% \\
)\end{array}$ & $\begin{array}{l}32 \\
8 \\
(1 \\
1.1 \\
\%)\end{array}$ & $\begin{array}{l}113 \\
(3 . \\
8 \% \\
)\end{array}$ & $\begin{array}{l}546 \\
(18 . \\
5 \% \\
)\end{array}$ & $\begin{array}{l}421 \\
(14 \\
.3 \\
\%)\end{array}$ & $\begin{array}{l}17 \\
(0 . \\
6 \% \\
)\end{array}$ & $\begin{array}{l}11 \\
(0 . \\
4 \\
\%)\end{array}$ & $\begin{array}{l}10 \\
-\mathrm{A} \\
(0 . \\
3 \\
\%) \\
3-\mathrm{I} \\
(0 . \\
1 \\
\%)\end{array}$ & $\begin{array}{l}1 \\
(0 . \\
03 \\
\%)\end{array}$ & - & - & - & - \\
\hline $\begin{array}{l}\text { Ioan } \\
\text { nido } \\
\text { u et } \\
\text { al. }\end{array}$ & $\begin{array}{l}\text { At } \\
\text { he } \\
\text { na }\end{array}$ & $\begin{array}{l}19 \\
77- \\
19 \\
87\end{array}$ & $\begin{array}{l}1 \\
0\end{array}$ & $\begin{array}{l}\mathrm{N} \\
\mathrm{M}\end{array}$ & $\begin{array}{l}50 \\
8\end{array}$ & $\begin{array}{l}303 \\
(59 . \\
6 \% \\
)\end{array}$ & $\begin{array}{l}14 \\
4 \\
(2 \\
8.4 \\
\%) \\
\end{array}$ & - & $\begin{array}{l}61 \\
(12 \\
\%)\end{array}$ & - & - & - & - & - & - & - & - & - \\
\hline $\begin{array}{l}\text { Aroti } \\
\text { ba et } \\
\text { al. }{ }^{56}\end{array}$ & $\begin{array}{l}\mathrm{Ni} \\
\mathrm{ge} \\
\text { ria }\end{array}$ & $\begin{array}{l}19 \\
82- \\
19 \\
96 \\
\end{array}$ & & $\begin{array}{l}7 \\
1 \\
5\end{array}$ & $\begin{array}{l}63 \\
(8 . \\
8 \% \\
)\end{array}$ & $\begin{array}{l}40 \\
(61 . \\
9 \% \\
)\end{array}$ & - & - & $\begin{array}{l}12 \\
(19 \\
\%)\end{array}$ & $\begin{array}{l}9 \\
(14 \\
.3 \\
\%)\end{array}$ & - & - & - & - & - & - & - & $\begin{array}{l}2 \\
(3.8 \\
\%)\end{array}$ \\
\hline $\begin{array}{l}\text { Al } \\
\text { Shed } \\
\text { di et } \\
\text { al. }\end{array}$ & $\begin{array}{l}\text { Sa } \\
\text { ud } \\
\mathrm{i} \\
\mathrm{Ar} \\
\mathrm{abi} \\
\mathrm{a}\end{array}$ & $\begin{array}{l}19 \\
84- \\
20 \\
10\end{array}$ & $\begin{array}{l}2 \\
6\end{array}$ & $\begin{array}{l}4 \\
4 \\
0 \\
8\end{array}$ & $\begin{array}{l}47 \\
0 \\
(11 \\
\%)\end{array}$ & $\begin{array}{l}302 \\
(64 . \\
3 \% \\
)\end{array}$ & $\begin{array}{l}31 \\
(6 . \\
6 \\
\%)\end{array}$ & $\begin{array}{l}5 \\
(1 . \\
1 \% \\
)\end{array}$ & $\begin{array}{l}118 \\
(25 . \\
1 \% \\
)\end{array}$ & $\begin{array}{l}\text { OK } \\
\mathrm{C} \downarrow \\
\text { OT }\end{array}$ & - & $\begin{array}{l}1 \\
(0 . \\
2 \\
\%)\end{array}$ & $\begin{array}{l}1 \\
(0 . \\
2 \\
\%)\end{array}$ & $\begin{array}{l}5 \\
(1 . \\
1 \% \\
)\end{array}$ & & & $\begin{array}{l}7 \\
(1 . \\
5 \% \\
)\end{array}$ & \\
\hline $\begin{array}{l}\text { Proc } \\
\text { kt } \\
\text { AP } \\
\text { et } \\
\text { al. } \\
{ }^{14}\end{array}$ & $\begin{array}{l}\mathrm{Br} \\
\text { azi } \\
1\end{array}$ & $\begin{array}{l}19 \\
85- \\
20 \\
05\end{array}$ & $\begin{array}{l}2 \\
0\end{array}$ & $\begin{array}{l}6 \\
5 \\
0 \\
3\end{array}$ & $\begin{array}{l}68 \\
0 \\
(10 \\
.45 \\
\%)\end{array}$ & $\begin{array}{l}493 \\
(72 . \\
5 \% \\
)\end{array}$ & $\begin{array}{l}29 \\
(4 . \\
26 \\
\%)\end{array}$ & $\begin{array}{l}4(0 \\
.58 \\
\%)\end{array}$ & $\begin{array}{l}151 \\
(22 . \\
2 \% \\
)\end{array}$ & $\begin{array}{l}28 \\
(3 . \\
95 \\
\%)\end{array}$ & $\begin{array}{l}2 \\
(0 . \\
29 \\
\%)\end{array}$ & $\begin{array}{l}1( \\
0.1 \\
5 \\
\%)\end{array}$ & - & - & - & - & - & - \\
\hline $\begin{array}{l}\text { Tort } \\
\text { orici } \\
\mathrm{S} \text { et } \\
\text { al. }^{20}\end{array}$ & $\begin{array}{l}\text { Si } \\
\text { cil } \\
y\end{array}$ & $\begin{array}{l}19 \\
86- \\
20 \\
05\end{array}$ & $\begin{array}{l}1 \\
9\end{array}$ & $\begin{array}{l}1 \\
2 \\
1 \\
9 \\
7\end{array}$ & $\begin{array}{l}12 \\
73 \\
(10 \\
.44 \\
\%)\end{array}$ & $\begin{array}{l}110 \\
7 \\
(84 . \\
5 \% \\
)\end{array}$ & - & - & $\begin{array}{l}149 \\
(11 . \\
4 \% \\
)\end{array}$ & $\begin{array}{l}17 \\
(1 . \\
3 \% \\
)\end{array}$ & - & - & - & - & - & - & - & - \\
\hline $\begin{array}{l}\text { Lede } \\
\text { sma- }\end{array}$ & $\begin{array}{l}\text { M } \\
\text { exi }\end{array}$ & $\begin{array}{l}19 \\
86-\end{array}$ & $\begin{array}{l}1 \\
0\end{array}$ & $\begin{array}{l}3 \\
8\end{array}$ & $\begin{array}{l}30 \\
4\end{array}$ & $\begin{array}{l}118 \\
(38 .\end{array}$ & $\begin{array}{l}15 \\
(4 .\end{array}$ & - & $\begin{array}{l}108 \\
(35 .\end{array}$ & $\begin{array}{l}57 \\
(18\end{array}$ & $\begin{array}{l}3 \\
(1\end{array}$ & $\begin{array}{l}3 \\
(1\end{array}$ & - & - & - & - & - & - \\
\hline
\end{tabular}




\begin{tabular}{|c|c|c|c|c|c|c|c|c|c|c|c|c|c|c|c|c|c|c|}
\hline $\begin{array}{l}\text { Mon } \\
\text { tes et } \\
\text { al. }{ }^{27}\end{array}$ & co & $\begin{array}{l}19 \\
96\end{array}$ & & $\begin{array}{l}6 \\
5\end{array}$ & $\begin{array}{l}(7 . \\
8 \% \\
)\end{array}$ & $\begin{array}{l}8 \% \\
)\end{array}$ & $\begin{array}{l}9 \\
\%)\end{array}$ & & $\begin{array}{l}5 \% \\
)\end{array}$ & $\begin{array}{l}.7 \\
\%)\end{array}$ & $\%)$ & $\%)$ & & & & & & \\
\hline $\begin{array}{l}\text { Khos } \\
\text { ravi } \\
\mathrm{N} \text { et } \\
\text { al. }{ }^{55}\end{array}$ & $\begin{array}{l}\text { Ira } \\
\mathrm{n}\end{array}$ & $\begin{array}{l}19 \\
88- \\
20 \\
10\end{array}$ & $\begin{array}{l}2 \\
3\end{array}$ & $\begin{array}{l}7 \\
4 \\
1 \\
2\end{array}$ & $\begin{array}{l}16 \\
03 \\
(21 \\
.62 \\
\%)\end{array}$ & $\begin{array}{l}563 \\
(35 . \\
12 \\
\%)\end{array}$ & $\begin{array}{l}20 \\
8 \\
(1 \\
2.9 \\
8 \\
\%)\end{array}$ & $\begin{array}{l}10 \\
(0 . \\
62 \\
\%)\end{array}$ & $\begin{array}{l}413 \\
(25 . \\
77 \\
\%)\end{array}$ & $\begin{array}{l}362 \\
(22 \\
.58 \\
\%)\end{array}$ & $\begin{array}{l}13( \\
0.8 \\
1 \% \\
)\end{array}$ & $\begin{array}{l}1( \\
0.0 \\
6 \\
\%)\end{array}$ & $\begin{array}{l}1- \\
A \\
(0 . \\
06 \\
\%)\end{array}$ & $\begin{array}{l}7 \\
(0 . \\
44 \\
\%)\end{array}$ & $\begin{array}{l}21 \\
(1 . \\
31 \\
\%)\end{array}$ & & $\begin{array}{l}4 \\
(0 . \\
25 \\
\%)\end{array}$ & \\
\hline $\begin{array}{l}\text { Batai } \\
\text { neh } \\
\text { et } \\
\text { al. }{ }^{10}\end{array}$ & $\begin{array}{l}\text { Jor } \\
\text { da } \\
\mathrm{n}\end{array}$ & $\begin{array}{l}19 \\
89- \\
20 \\
01\end{array}$ & $\begin{array}{l}1 \\
2\end{array}$ & $\begin{array}{l}\mathrm{N} \\
\mathrm{M}\end{array}$ & $\begin{array}{l}65 \\
4\end{array}$ & $\begin{array}{l}273 \\
(41 . \\
7 \% \\
)\end{array}$ & $\begin{array}{l}12 \\
9 \\
(1 \\
9.7 \\
\%)\end{array}$ & - & $\begin{array}{l}162 \\
(24 . \\
8 \% \\
)\end{array}$ & $\begin{array}{l}39 \\
(6 \\
\%)\end{array}$ & $\begin{array}{l}51 \\
(7 . \\
8 \% \\
)\end{array}$ & - & - & - & $\begin{array}{l}\mathrm{CO} \\
\mathrm{C} \downarrow \\
\mathrm{OT}\end{array}$ & - & - & - \\
\hline $\begin{array}{l}\text { El } \\
\text { Geha } \\
\text { ni R } R \\
\text { et } \\
\text { al. }{ }^{36}\end{array}$ & $\begin{array}{l}\mathrm{Li} \\
\text { by } \\
\text { a }\end{array}$ & $\begin{array}{l}19 \\
90- \\
20 \\
05\end{array}$ & $\begin{array}{l}1 \\
5\end{array}$ & $\begin{array}{l}2 \\
1 \\
9 \\
0\end{array}$ & $\begin{array}{l}32 \\
6 \\
(14 \\
.8 \\
\%)\end{array}$ & $\begin{array}{l}222 \\
(68 . \\
1 \% \\
)\end{array}$ & - & - & $\begin{array}{l}49 \\
(15 \\
\%)\end{array}$ & $\begin{array}{l}46 \\
(14 \\
.1 \\
\%)\end{array}$ & $\begin{array}{l}5 \\
(1 . \\
5 \% \\
)\end{array}$ & $\begin{array}{l}3 \\
(0 . \\
9 \\
\%)\end{array}$ & - & $\begin{array}{l}1 \\
(0 . \\
3 \% \\
)\end{array}$ & - & - & - & - \\
\hline $\begin{array}{l}\text { Avel } \\
\text { ar } \\
\text { RL } \\
\text { et } \\
\text { al. }^{15}\end{array}$ & $\begin{array}{l}\mathrm{Br} \\
\text { azi } \\
1\end{array}$ & $\begin{array}{l}19 \\
92- \\
20 \\
07\end{array}$ & $\begin{array}{l}1 \\
5\end{array}$ & $\begin{array}{l}5 \\
1 \\
0 \\
0\end{array}$ & $\begin{array}{l}50 \\
7 \\
(9 . \\
94 \\
\%)\end{array}$ & $\begin{array}{l}265 \\
(52 . \\
27 \\
\%)\end{array}$ & $\begin{array}{l}30 \\
(5 . \\
91 \\
\%)\end{array}$ & $\begin{array}{l}28 \\
(5 . \\
52 \\
\%)\end{array}$ & $\begin{array}{l}156 \\
(30 . \\
7 \% \\
)\end{array}$ & $\begin{array}{l}\text { OK } \\
\mathrm{C} \downarrow \\
\text { OT }\end{array}$ & $\begin{array}{l}11 \\
(2 . \\
1 \% \\
)\end{array}$ & $\begin{array}{l}8 \\
(1 . \\
55 \\
\%)\end{array}$ & $\begin{array}{l}5- \\
\text { A } \\
(0 . \\
9 \\
\%)\end{array}$ & $\begin{array}{l}4 \\
(0 . \\
7 \% \\
)\end{array}$ & - & - & - & - \\
\hline $\begin{array}{l}\text { Meni } \\
\text { ngau } \\
\text { d JP } \\
\text { et } \\
\text { al. }\end{array}$ & $\begin{array}{l}\text { Fr } \\
\text { an } \\
\text { ce }\end{array}$ & $\begin{array}{l}19 \\
95- \\
20 \\
05\end{array}$ & $\begin{array}{l}1 \\
0\end{array}$ & $\begin{array}{l}\mathrm{N} \\
\mathrm{M}\end{array}$ & $\begin{array}{l}69 \\
5\end{array}$ & $\begin{array}{l}372 \\
(53 . \\
5 \% \\
)\end{array}$ & $\begin{array}{l}32 \\
(4 . \\
6 \\
\%)\end{array}$ & - & $\begin{array}{l}154 \\
(22 . \\
3 \% \\
)\end{array}$ & $\begin{array}{l}133 \\
(19 \\
.1 \\
\%)\end{array}$ & $\begin{array}{l}2 \\
(0 . \\
2 \% \\
)\end{array}$ & - & - & $\begin{array}{l}2 \\
(0 . \\
2 \% \\
)\end{array}$ & - & - & - & - \\
\hline $\begin{array}{l}\text { Nuñ } \\
\text { ez- } \\
\text { Urru } \\
\text { tia S } \\
\text { et } \\
\text { al. }\end{array}$ & $\begin{array}{l}\mathrm{Sp} \\
\text { ain }\end{array}$ & $\begin{array}{l}19 \\
97- \\
20 \\
06\end{array}$ & $\begin{array}{l}0 \\
9\end{array}$ & $\begin{array}{l}1 \\
2 \\
3 \\
5\end{array}$ & $\begin{array}{l}41 \\
8 \\
(33 \\
.8 \\
\%)\end{array}$ & $\begin{array}{l}210 \\
(50 . \\
2 \% \\
)\end{array}$ & $\begin{array}{l}18 \\
(4 . \\
3 \\
\%)\end{array}$ & $\begin{array}{l}87 \\
(20 \\
.8 \\
\%)\end{array}$ & $\begin{array}{l}91 \\
(21 . \\
8 \% \\
)\end{array}$ & $\begin{array}{l}4 \\
(1 \\
\%)\end{array}$ & $\begin{array}{l}7 \\
(1 . \\
7 \% \\
)\end{array}$ & - & $\begin{array}{l}1- \\
A \\
(0 . \\
2 \\
\%)\end{array}$ & - & - & - & - & - \\
\hline $\begin{array}{l}\text { Akra } \\
\text { m S } \\
\text { et } \\
\text { al. }\end{array}$ & $\begin{array}{l}\mathrm{Pa} \\
\text { kis } \\
\text { tan }\end{array}$ & $\begin{array}{l}20 \\
01- \\
20 \\
11\end{array}$ & $\begin{array}{l}1 \\
0\end{array}$ & $\begin{array}{l}6 \\
0 \\
0 \\
0\end{array}$ & $\begin{array}{l}10 \\
0 \\
(1 . \\
6 \%\end{array}$ & $\begin{array}{l}53 \\
(53 \\
\%)\end{array}$ & $\begin{array}{l}4 \\
(4 \\
\%)\end{array}$ & $\begin{array}{l}7 \\
(7 \\
\%)\end{array}$ & $\begin{array}{l}34 \\
(34 \\
\%)\end{array}$ & $\begin{array}{l}\text { OK } \\
\mathrm{C} \downarrow \\
\text { OT }\end{array}$ & - & - & $\begin{array}{l}2- \\
\text { A } \\
(2 \\
\%)\end{array}$ & - & - & - & - & - \\
\hline $\begin{array}{l}\text { Pres } \\
\text { ent } \\
\text { Stud } \\
\text { y }\end{array}$ & $\begin{array}{l}\text { In } \\
\text { di } \\
\text { a }\end{array}$ & $\begin{array}{l}19 \\
81- \\
20 \\
15\end{array}$ & $\begin{array}{l}3 \\
5\end{array}$ & $\begin{array}{l}6 \\
5 \\
0 \\
9\end{array}$ & $\begin{array}{l}12 \\
42 \\
(19 \\
.08 \\
\%)\end{array}$ & $\begin{array}{l}591 \\
(55 . \\
54)\end{array}$ & $\begin{array}{l}74 \\
(6 . \\
95 \\
)\end{array}$ & $\begin{array}{l}01( \\
0.0 \\
9 \% \\
)\end{array}$ & $\begin{array}{l}126 \\
(11 . \\
84)\end{array}$ & $\begin{array}{l}146 \\
(13 \\
.72 \\
)\end{array}$ & $\begin{array}{l}02( \\
0.1 \\
8 \% \\
)\end{array}$ & - & - & $\begin{array}{l}02( \\
0.1 \\
8 \% \\
)\end{array}$ & $\begin{array}{l}06( \\
0.5 \\
6 \% \\
)\end{array}$ & - & $\begin{array}{l}03( \\
0.2 \\
9 \% \\
)\end{array}$ & $\begin{array}{l}113( \\
10.6 \\
2 \%)\end{array}$ \\
\hline
\end{tabular}

B-Biopsy, Yrs.-Years, NM-Not mentioned, OC-Odontogenic cyst, RC-Radicular Cyst, ResC-Residual Cyst, PCParadental Cyst, DC-Dentigerous cyst, OKC-OdontogenicKeratocyst, LPC-Lateral Periodontal Cyst, EC-Eruption Cyst, GC-Gingival cyst, A-Adult, I-Infant, GOC-Glandular Odontogenic Cyst, COC-Calcifying Odontogenic Cyst, BOC-BotyroidOdontogenic Cyst, OOC-OrthokeratinizedOdontogenic Cyst, UOC-Unclassifiable Odontogenic Cyst, $\downarrow$ OT-Under Odontogenic tumors 
Tables 7:- Geographic variation of Odontogenic and Non-Odontogenic cysts from selected references

\begin{tabular}{|c|c|c|c|c|c|c|}
\hline Author & Present Study & $\begin{array}{l}\text { Grossman et } \\
\text { al. }{ }^{3}\end{array}$ & $\begin{array}{l}\text { Tekkesin } \\
\text { MS et al. }^{4}\end{array}$ & Daley TD et al. ${ }^{2}$ & Butt et al. ${ }^{59}$ & $\begin{array}{l}\text { Açikgöz A, } \\
\text { et al. }\end{array}$ \\
\hline Place & India & Brazil & Turkey & Canada & $\begin{array}{l}\text { Nairobi, } \\
\text { Kenya }\end{array}$ & $\begin{array}{l}\text { Samsun, } \\
\text { Turkey }\end{array}$ \\
\hline $\begin{array}{l}\text { Duration } \\
\text { (Yrs.) }\end{array}$ & $\begin{array}{l}1981-2015 \\
(35)\end{array}$ & $\begin{array}{l}1953-2003 \\
(50)\end{array}$ & $\begin{array}{l}1971-2010 \\
(40)\end{array}$ & $1967-1993(26)$ & $\begin{array}{l}1991-2010 \\
(20)\end{array}$ & $\begin{array}{l}2000-2008 \\
(8)\end{array}$ \\
\hline $\begin{array}{l}\text { Total } \\
\text { Biopsies }\end{array}$ & 6509 & 19064 & 42,296 & 40,000 & 4257 & 12350 \\
\hline $\begin{array}{l}\text { Total } \\
\text { Cysts }\end{array}$ & $1242(19.08 \%)$ & $\begin{array}{l}2905 \\
(15.24 \%)\end{array}$ & $\begin{array}{l}5088 \\
(12.03 \%)\end{array}$ & $7246(18.12 \%)$ & $194(4.56 \%)$ & $459(3.72 \%)$ \\
\hline $\mathrm{OC}$ & $1064(85.67 \%)$ & $2812(96.8 \%)$ & $\begin{array}{l}5003 \\
(98.3 \%)\end{array}$ & $6847(94.49 \%)$ & $111(57.2 \%)$ & $452(98.5 \%)$ \\
\hline NOC & $178(14.33 \%)$ & $93(3.2 \%)$ & $85(1.7 \%)$ & $399(5.50 \%)$ & $83(42.8 \%)$ & $7(1.5 \%)$ \\
\hline $\mathrm{RC}$ & $591(47.58 \%)$ & $1772(61 \%)$ & $\begin{array}{l}2802 \\
(55.09 \%)\end{array}$ & $4461(61.56 \%)$ & $43(22 \%)$ & $251(54.68 \%)$ \\
\hline Res C & $74(5.96 \%)$ & - & $482(9.47 \%)$ & Included with RC & - & $63(13.72 \%)$ \\
\hline $\mathrm{PC}$ & $1(0.08 \%)$ & $19(0.7 \%)$ & $11(0.2 \%)$ & $33(0.45 \%)$ & - & - \\
\hline$\overline{\mathrm{DC}}$ & $126(10.14 \%)$ & $735(25.3 \%)$ & $\begin{array}{l}529 \\
(10.39 \%)\end{array}$ & $1649(22.76 \%)$ & $61(31 \%)$ & $122(26.57 \%)$ \\
\hline OKC & $146(11.75 \%)$ & $208(7.2 \%)$ & $1048(20.6 \%)$ & $334(4.61 \%)$ & $\begin{array}{l}\text { OKC under } \\
\text { OT }\end{array}$ & $15(3.27 \%)$ \\
\hline LPC & $2(0.16 \%)$ & $7(0.2 \%)$ & $6(0.12 \%)$ & $101(1.39 \%)$ & $2(1 \%)$ & $1(0.22 \%)$ \\
\hline ErC & - & $26(0.9 \%)$ & $1(0.02 \%)$ & $40(0.55 \%)$ & $4(2 \%)$ & - \\
\hline GC & - & $\begin{array}{l}1(0.03 \%) \mathrm{A} \\
1(0.03 \%) \mathrm{I}\end{array}$ & - & $33(0.45 \%) \mathrm{A}$ & $1(0.5 \%)-\mathrm{I}$ & - \\
\hline GOC & $2(0.16 \%)$ & $2(0.07 \%)$ & $23(0.45 \%)$ & $3(0.04 \%)$ & - & - \\
\hline $\mathrm{COC}$ & $6(0.48 \%)$ & $30(1 \%)$ & $33(0.65 \%)$ & - & $\begin{array}{l}\text { COC under } \\
\text { OT }\end{array}$ & - \\
\hline BOC & - & $2(0.07 \%)$ & $2(0.04 \%)$ & - & - & - \\
\hline $\mathrm{OOC}$ & $3(0.24 \%)$ & $9(0.3 \%)$ & - & - & - & - \\
\hline $\mathrm{UOC}$ & $113(9.10 \%)$ & - & $66(1.3 \%)$ & $193(2.66 \%)$ & - & - \\
\hline NPC & $5(0.40 \%)$ & $64(2.2 \%)$ & $66(1.3 \%)$ & $293(4.04 \%)$ & $51(26.3 \%)$ & - \\
\hline NLC & $7(0.56 \%)$ & $29(1 \%)$ & $2(0.04 \%)$ & $7(0.09 \%)$ & - & $7(1.52 \%)$ \\
\hline BLEC & $1(0.08 \%)$ & - & - & $65(0.89 \%)$ & $4(2.1 \%)$ & - \\
\hline DerC & $6(0.48 \%)$ & - & - & $1(0.01 \%)$ & $5(2.6 \%)$ & - \\
\hline $\mathrm{EC}$ & $5(0.43 \%)$ & - & - & $21(0.29 \%)$ & $13(6.7 \%)$ & - \\
\hline Others & $\begin{array}{l}\text { Muc-145 } \\
(11.67 \%) \\
\text { SC-3(0.24\%) } \\
\text { SCC- } \\
\text { 3(0.24\%) } \\
\text { TBC- } \\
\text { 1(0.08\%) } \\
\text { CC-1(0.08\%) } \\
\text { MucMx A-1 } \\
(0.08 \%)\end{array}$ & - & $\begin{array}{l}\text { GMC-9 } \\
(0.18 \%) \\
\text { MMC-5 } \\
(0.1 \%) \\
\text { MPC-3 } \\
(0.05 \%)\end{array}$ & $\begin{array}{l}\text { SCC-6(0.08\%) } \\
\text { SC-3(0.04\%) } \\
\text { UOC-1(0.01\%) } \\
\text { MMC-1 }(0.01 \%) \\
\text { Steatocystoma } \\
\text { simplex-1 }(0.01 \%)\end{array}$ & $\begin{array}{l}\text { ABC- } \\
5(2.6 \%) \\
\text { Thyroglossal } \\
\text { C-4(2.1\%) } \\
\text { Cystic } \\
\text { Hygroma- } \\
1(0.5 \%)\end{array}$ & \\
\hline
\end{tabular}

B-Biopsy, Yrs.-Years, C-Cyst, OC-Odontogenic cyst, NOC-Non-Odontogenic cyst, RC-Radicular Cyst, Res CResidual Cyst, PC-Paradental Cyst, DC-Dentigerous cyst, OKC-OdontogenicKeratocyst, LPC-Lateral Periodontal Cyst, ErC-Eruption Cyst, GC-Gingival cyst, A-Adult, I-Infant, GOC-Glandular Odontogenic Cyst, COC-Calcifying Odontogenic Cyst, BOC-BotyroidOdontogenic Cyst, OOC-OrthokeratinizedOdontogenic Cyst, UOC-Unclassifiable Odontogenic Cyst, $\downarrow$ OT-Under Odontogenic tumors, NPC-Nasopalatine Cyst, NLC-Nasolabial cyst, BLEC-Benign lymphoepithelial cyst, DerC-Dermoid Cyst, EC-Epidermoid Cyst, SC-Sebaceous Cyst, SCC-Surgical Ciliated Cyst, TBC-Traumatic bone Cyst, CC-CysticercusCellulosae, Muc-Mucocele, Mx A-Maxillary Antrum, MMC-Median Mandibular Cyst, GMC-Globulomaxillary Cyst, MPC-MedianPalatine Cyst, ABC-Aneurysmal Bone Cyst 


\section{References:-}

1. Acikgoz A, Uzun-Bulut E, Ozden B, Gunduz K. Prevalence and distribution of odontogenic and non odontogenic cysts in Turkish population. Med Oral Patol Oral Cir Bucal. 2012; 17(1):e108-15.

2. Akram S, Naghma, Ali MA, Shakir MM. Prevalence of Odontogenic cysts and Tumors in Karachi, Pakistan. J Dow Uni Health Sci. 2013; 7 (1): 20-4.

3. Al Sheddi MA.Odontogenic cysts: A clinicopathological study. Saudi Med J.2012; 33(3):304-8.

4. Al-Khateeb TH1, Al-Masri NM, Al-Zoubi F. Cutaneous cysts of the head and neck. J Oral Maxillofac Surg. 2009; 67(1):52-7.

5. Altini M, Shear M. The lateral periodontal cyst: an update. J Oral Pathol Med.1992;21(6):245-50.

6. Arotiba JT, Lawoyin JO, Obiechina AE. Pattern of occurrence of Odontogenic cysts in Nigerians. East Afr Med J. 1998; 75(11):664-6.

7. Avelar RL, Antunes AA, Carvalho RW, Bezerra PG, Oliveira Neto PJ, Andrade ES. Odontogenic cysts: a clinicopathologic study of 507 cases.J Oral Sci.2009; 51(4):581-6.

8. Bataineh AB, Rawashdeh MA, Al Qudah MA. The prevalence of inflammatory and developmental odontogenic cysts in a Jordanian population: a clinicopathologic study. Quintessence Int. 2004; 35(10):815-19.

9. Borges LB, Fechine FV, Mota MRL, Sousa FB, Alves APNN. Odontogenic lesions of the jaw: a clinicalpathological study of 461 cases. Revista Gaúcha de Odontologia Destaques.2012; 60:71-8.

10. Bornstein MM, Filippi A, Altermatt HJ, et al. The odontogenic keratocyst-odontogenic cyst or benign tumor? Schweiz Monatsschr Zahnmed. 2005; 115(2):110-28.

11. Butt FMA, Ogeng'o J, Bahra J, Chindia ML. Pattern of Odontogenic and Non odontogenic Cysts. J Craniofac Surg.2011; 22 (6):2160-2.

12. Daley TD, Wysocki GP, Pringle GA. Relative incidence of odontogenic tumors and oral and jaw cysts in a Canadian population. Oral Surg Oral Med Oral Pathol. 1994;77(3):276-80.

13. de Souza LB, Gordón-Núñez MA, Nonaka CF, de Medeiros MC, Torres TF, Emiliano GB. Odontogenic cysts: demographic profile in a Brazilian population over a 38-year period. Med Oral Patol Oral Cir Bucal. 2010; 15(4):e583-90.

14. Deepthi PV, Beena VT, Padmakumar SK, Rajeev R, SivakumarR. A study of 1177 odontogenic lesions in a South Kerala.J Oral Maxillofac Pathol 2016;20(2):202-7

15. Dong Q, Pan S, Sun LS, Li TJ. Orthokeratinized Odontogenic Cyst: A Clinicopathologic Study of 61 Cases. Arch Pathol Lab Med.2010; 134:271-75.

16. El Gehani R, Krishnan B, Orafi H. The prevalence of inflammatory and developmental odontogenic cysts in a Libyan population. Libyan J Med.2008; 3(2):75-7.

17. Grossmann SM, Machado VC, Xavier GM, Moura MD, Gomez RS, Aguiar MC, Mesquita RA. Demographic profile of odontogenic and selected non odontogenic cysts in a Brazilian population. Oral Surg Oral Med Oral Pathol Oral Radiol Endod. 2007;104(6): e35-41.

18. Happonen RP, Ylipaavalniemi P, Calonius B. A survey of 15,758 oral biopsies in Finland. Proc Finn Dent Soc. 1982; 78(4): 201-6.

19. High AS, Main DM, Khoo SP, Pedlar J, Hume WJ. The polymorphous odontogenic cyst. J Oral Pathol Med 1996; 25: 25-31.

20. Ioannidou F, Mustafa B, Seferiadou-Mavropoulou T. Odontogenic cysts of the jaws: A clinicostatistical study.Stomatologia (Athenai).1989; 46(2):81-90.

21. Jones AV, Craig GT, Franklin CD. Range and demographics of odontogenic cysts diagnosed in a UK population over a 30-year period. J Oral Pathol Med.2006; 35(8): 500-7.

22. Jones AV, Franklin CD. A survey of oral and maxillofacial pathology specimens submitted by general dental practitioners over a 30-year period. Br Dent J 2006; 200: 447-50.

23. Khosravi N, Razavi SM, Kowkabi M, Navabi A.A. Demographic distribution of odontogenic cysts in Isfahan (Iran) for a 23 year period (1988-2010). Dent Res J.2013; 10(2):162-7.

24. Kochaji N Pipeleers-Marichal M, Goossens A, Wackens G and Bottenberg P. Epidemiological study of jaw cysts among a part of the Belgian population. Oral Med Pathol. 2003; 8:71-3.

25. Koseoglu BG, Atalay B, Erdem MA. Odontogenic cysts: a clinical study of 90 cases. J Oral Sci.2004; 46(4):253-7.

26. Lawal AO, Adisa AO, Sigbeku OF. Cysts of the oro-facial region: A Nigerian experience. J Oral Maxillofac Pathol.2012; 16:167-71.

27. Ledesma-Montes C, Hernández- Guerrero JC, Garcés-OrtízM.Clinicopathologic study of odontogenic cysts in a Mexican sample population. Arch Med Res 2000;31:373-376

28. Longo F, Maremonti P, Mangone GM, De Maria G, Califano L. Midline (dermoid) cysts of the floor of the 
mouth: report of 16 cases and review of surgical techniques. Plast Reconstr Surg. 2003; 112(6):1560-5.

29. Lopes-Rocha R, Dornela Verli F, Lages Lima N, Rocha Dos Santos CR, Aparecida Marinho S. Nasolabial cyst:18.5 year experience in a pathology laboratory. Minerva Stomatol.2011; 60(11-12):567-72.

30. MacDonald-Jankowski DS, Li TK. Orthokeratinized odontogenic cysts in Hong Kong community: the clinical and radiological features. Dentomaxillofac Radiol.2010; 39(4):240-5.

31. Masthan KMK, Rajkumari S, Deepasree M, Babu1 NA, Sankari SL. Neoplasms associated with odontogenic cysts. J Dent Oral Hyg. 2011; 3(10):123-30.

32. Meningaud JP, Oprean N, Pitak-Arnnop P, Bertrand JC. Odontogenic cysts:A clinical study of 695 cases. J Oral Sci.2006; 48(2):59-62.

33. Moctezuma-Bravo GS, Magallanes-Gonzalez E. Study of 103 cases of odontogenic cysts. Rev Med Inst Mex Seguro Soc. 2009; 47(5):493-6.

34. Mohammad Shafi Dar, Shazya Gul, Latief Najar and Zahoor Ahmad Bhat. Retrospective Study of Demographic Profile of Odontogenic and Non-Odontogenic Cysts in Uttarpradesh Population, India. Int.J.Curr.Microbiol.App.Sci.2016;5(4): 778-83.

35. Mosqueda Taylor A,Irigoyen-Camacho ME, Diaz-Franco MA, Torres Tejero MA. Odontogenic cysts: Analysis of 856 cases.Med Oral.2002;7(2):89-96.

36. Nakamura T, Ishida J, Nakano Y et al. A study of cysts in the oral region. Cysts of the jaw. J Nihon Univ Sch Dent 1995; 37: 33-40.

37. Narang RS, Manchanda AS, Arora P, Randhawa K. Dentigerous cyst of inflammatory origin- a diagnostic dilemma. Ann Diagn Pathol.2012; 16(2):119-23.

38. Nasrollah Saghravanian, Reza Zare-Mahmoodabadi, Narges Ghazi, Saleh Hosseinpour. Odontogenic cysts: A 40- year retrospective clinicopathological study in an Iranian population. Cumhuriyet Dent J 2015; 18(3):272281.

39. NiranjanKC and ZulfinShaikh.Clinicopathological correlation of odontogenic cysts and tumors in a South Indian population over a 20-year period .International J of Dent.Res.2. (2)2014, 32-36.

40. Nuñez-Urrutia S, Figueiredo R, Gay-Escoda C. Retrospective clinicopathologicalstudy of 418 odontogenic cysts. Med Oral Patol Oral Cir Bucal. 2010; 15 (5):e767-73.

41. Ochsenius G, Escobar E, Godoy L, Penafiel C. Odontogenic cysts: analysis of 2,944 cases in Chile. Med Oral Patol Oral Cir Bucal.2007; 12(2):E85-91.

42. Ogunlewe MO, Odukoya O, Akinwande JA. Epithelial jaw cysts. Analysis of 126 Nigerian cases. Afr Dent J. 1996; 10:1-8.

43. Prockt AP,Schebela CR, Maito FD, Sant'Ana-Filho M, Rados PV. Odontogenic cysts: analysis of 680 cases in Brazil.Head Neck Pathol.2008;2(3):150-6.

44. Pryor SG, Lewis JE, Weaver AL, Orvidas LJ. Pediatric dermoid cysts of the head and neck. Otolaryngol Head Neck Surg. 2005; 132(6):938-42.

45. Ramachandra P, Maligi P, Raghuveer HP. Acumulative analysis of odontogenic cysts from major dental institutions ofBangalore city: A study of 252 cases. J Oral Maxillofac Pathol .2011; 15(1):1-5.

46. Rao K. Smitha, Umadevi HS, Priya NS. Clinicopathological study of 100 Odontogenic cysts reported at V S Dental College- a Retrospective Study. J Adv Dent Res.2011;2(1):51-7

47. RaviKumar H, Ravishankar MN, Shashikaran HC, Jain R. Odontogenic cysts- A clinicopathological study of 120 cases. IOSR J Dent Med Sci. 2014; 13 (5) Ver. I: 77-9.

48. Reichart PA, Philipsen HP, Sciubba JJ. The new classification of head and neck tumours (WHO) - any changes? Oral Oncol. 2006; 42(8):757-8.

49. Sanatkhani M, Zarch HH, Pakfetrat A, Falaki F. Odontogenic Cysts: a Clinical and Radiographic Study of 58 Cases. Aust J Basic Applied Sci.2011; 5:329-33.

50. Sandhu SV, Narang RS, Jawanda M, Rai S. Adenomatoid odontogenic tumour associated with dentigerous cyst of the maxillary antrum: A rare entity. J Oral Maxillofac Pathol.2010; 14(1): 24-8.

51. Selvamani M, Donoghue M, Basandi PS. Analysis of 153 cases of odontogeniccysts in a South Indian samplepopulation: a retrospective study overa decade. Braz Oral Res. 2012; 26(4):330-4.

52. Shear M, Speight P. Cysts of the Oral and Maxillofacial regions. In Shear M, Speight P, editors. $4^{\text {th }}$ ed. Blackwell Munksgaard; 2007.

53. Tekkesin MS, Olgac V, Aksakalli N, Alatli C. Odontogenic and Non odontogenic cysts in Istanbul: Analysis of 5088 cases. Head Neck.2011;34(6):852-5.

54. Tilakaratne WM. Ch 5.Cysts of Oral and Maxillofacial region. In Oral Medicine and Pathology: a guide to diagnosis and management. Edited by Warnakulasuriya, Tilakratne WM. $1^{\text {st }}$ ed.2014. Jaypee Brothers Medical Publishers. 
55. Tortorici S , Amodio E, Massenti MF, Buzzanca ML, Burruano F, Vitale F. Prevalence and distribution of odontogenic Cysts in Sicily 1986-2005. J Oral Sci.2008; 50(1):15-8.

56. Varinauskas V, Gervickas A, Kavoliuniene. Analysis of odontogenic cysts of the jaws. Medicina (Kaunas).2006; 42(3): 201-7.

57. Vasconcelos RF, Souza PE, Mesquita RA. Retrospective analysis of 15 cases of nasolabial cyst. Quintessence Int. 1999; 30(9):629-32.

58. Waldron CA.Odontogenic cysts and tumors.In Oral and Maxillofacial Pathology, Neville BW,Damm DD, Allen CM, Bouquot JE eds, W.B.Saunders, Philadelphilia,1995:493-540.

59. Wright JH \& Vered Marilena Update from the $4^{\text {th }}$ edition of the world health organisation classification of head and neck tumours: odontogenic and Maxillofacial Bone tumors. Head and Neck Pathol 2017.DOI 10.1007/s12105-017-0794-1

\section{Acknowledgement:-}

To, Dr. Mansingh Pawar, Dean ,Government Dental College and Hospital ,Mumbai for his support and encouragement towards conducting this study. 